\title{
Identifying critical transitions in seasonal shifts of zooplankton composition in a confined coastal salt marsh
}

\author{
Xavier D. Quintana ${ }^{1}\left[\right.$ C Maria Antón-Pardo $^{1} \cdot$ Maria Bas-Silvestre $^{1} \cdot$ Dani Boix $^{1} \cdot$ Xavier Casamitjana $^{2}$. Jordi Compte ${ }^{1}$. \\ David Cunilllera-Montcusí ${ }^{1,3}$. Stéphanie Gascón ${ }^{1} \cdot$ Anna Menció $^{4} \cdot$ Biel Obrador $^{5}$ - Irene Tornero ${ }^{1}$ · Jordi Sala ${ }^{1}$
}

Received: 22 August 2020 / Accepted: 21 August 2021 / Published online: 7 September 2021

(C) The Author(s) 2021

\begin{abstract}
Zooplankton assemblages in the confined coastal lagoons of La Pletera salt marshes (Baix Ter wetlands, Girona, Spain) are dominated by two species: one calanoid copepod (Eurytemora velox) and the other rotifer (Brachionus gr. plicatilis). They alternate as the dominant species (more than $80 \%$ of total zooplankton biomass), with the former being dominant in winter and the latter in summer. Shifts between these taxa are sudden, and intermediate situations usually do not last more than 1 month. Although seasonal shifts between zooplankton dominant species appear to be related with temperature, other factors such as trophic state or oxygen concentration may also play an important role. Shifts between species dominances may be driven by thresholds in these environmental variables. However, according to the alternative stable states theory, under conditions of stable dominance a certain resistance to change may exist, causing that gradual changes might have little effect until a tipping point is reached, at which the reverse change becomes much more difficult. We investigated which are the possible factors causing seasonal zooplankton shifts. We used high-frequency temperature and oxygen data provided by sensors installed in situ to analyse if shifts in zooplankton composition are determined by a threshold in these variables or, on the other hand, some gradual change between stable states occur. Moreover, following the postulates of the alternative stable states theory, we looked at possible hysteresis to analyse if these seasonal zooplankton shifts behave as critical transitions between two different equilibriums. We also examined if top-down or bottom-up trophic interactions affect these zooplankton shifts. Our results show that shifts between dominant zooplankton species in La Pletera salt marshes are asymmetric. The shift to a Eurytemora situation is mainly driven by a decrease in temperature, with a threshold close to $19^{\circ} \mathrm{C}$ of daily average temperature, while the shift to Brachionus does not. Usually, the decrease in water temperature is accompanied by a decrease in oxygen oscillation with values always close to $100 \%$ oxygen saturation. Moreover, oxygen and temperature values before the shift to calanoids are different from those before the reverse shift to Brachionus, suggesting hysteresis and some resistance to change when a critical transition is approaching. Top-down and bottom-up forces appear to have no significant effect on shifts, since zooplankton biomass was not negatively correlated with fish biomass and was not positively related with chlorophyll, in overall data or within shifts.
\end{abstract}

Keywords Shallow lakes $\cdot$ Alternative stable states $\cdot$ Tipping points $\cdot$ Brachionus plicatilis $\cdot$ Eurytemora velox

Xavier D. Quintana

xavier.quintana@udg.edu

1 GRECO Institute of Aquatic Ecology, University of Girona, Av. Ma Aurèlia Capmany, 69, 17003 Girona, Spain

2 Department of Physics, University of Girona, 17003 Girona, Spain

3 WasserCluster Lunz, Biologische Station GmbH,

Lunz am See, Austria
4 Grup de Geologia Ambiental i Aplicada (GAiA), Department of Environmental Sciences, University of Girona, 17003 Girona, Spain

5 Department of Evolutionary Biology, Ecology and Environmental Sciences, Biodiversity Research Institute (IRBio), University of Barcelona, 08028 Barcelona, Spain 


\section{Introduction}

Physical variability across environmental gradients, biotic effects mediated by top-down or bottom-up forces as well as the trade-offs by constraining traits on species involved determine zooplankton community structure in shallow lakes (Wiggins et al. 1980; McQueen et al. 1986; Tilman 1987; Wellborn et al. 1996; Meerhoff et al. 2012; Batzer and Boix 2016; Gascón et al. 2016; Tavşanoğlu et al. 2017). Dominances of single species in zooplankton assemblages are often described as a consequence of competitive exclusion under low predation pressure (Gliwicz et al. 2010; Kerfoot and DeMott 1984) or of extreme environmental constraints, such as those caused by temperature (Herbert and Hann 1986; Lau et al. 2020), temperature fluctuations (Zhang et al. 2018) or salinity (Boix et al. 2007, 2008; Waterkeyn et al. 2008; Brucet et al. 2009, 2012). Regarding salinity, monospecific zooplankton assemblages can be found under extremely high salinities or strong salinity fluctuations in time or space both in inland (Comín et al. 1983; Girgin et al. 2004; Horváth et al. 2014; Tóth et al. 2014) or coastal (Attayde and Bozelli 1998; Brucet et al. 2010; Emir Akbulut and Tavşanoğlu 2018) brackish or saline waters. This is the case of Mediterranean confined coastal lagoons, which are subjected to strong variations in water level, salinity and nutrient concentrations due to the lack of a continuous surface connection with the sea or with the adjacent freshwater habitats (Quintana et al. 1998b, 2018; Menció et al. 2017; Casamitjana et al. 2019). Although many marine or freshwater species may arrive at these lagoons during sea storms or flooding events, only few euryhaline species tolerate these sharp salinity fluctuations and achieve stable populations (Cognetti and Maltagliati 2000; Gascón et al. 2005). Therefore, diversity in zooplankton assemblages in these ecosystems is usually low, with the dominant species often representing more than $80 \%$ of total zooplankton biomass (Quintana et al. 1998a; Brucet et al. 2006). A succession of zooplankton dominances related to changes in hydrology and trophic state has been described in brackish and temporary confined water bodies (Quintana et al. 1998a, 2006). Similar alternations among single zooplankton species have also been described in permanent water bodies with high fish density, as is the case of La Pletera salt marshes, with seasonal changes between calanoids (mainly Eurytemora velox) and Brachionus rotifers (almost exclusively a species of the Brachionus plicatilis complex), the former dominating in winter, when organic matter concentration is low, and the latter in summer, coinciding with increases in organic matter and with strong oxygen oscillations giving oversaturation during the day and hypoxia during the night (Badosa et al. 2007; Cabrera et al. 2019; Bas-Silvestre et al. 2020).

Shifts between Brachionus and E. velox may be caused by variations in environmental conditions such as temperature or trophic state, but also may be the consequence of trophic interactions, including bottom-up limitation or competition for resources or different response to top-down predatory pressure (Peters and Downing 1984; Carpenter et al. 1985; McQueen et al. 1986). Both species are filter-feeding grazers (Pagano and Gaudy 1986; Wallace et al. 2006), but Brachionus is a non-selective microbivore, feeding mainly on bacteria or small picoplankton (Herklo $\beta$ and Hlawa 1995; Navarro 1999), while Eurytemora usually select larger prey (Boak and Goulder 1983; Kunzmann et al. 2019). Regarding response to predation, Brachionus and E. velox strongly differ in size and, thus, can differ in their sensitivity to planktonic fish predation (Brooks and Dodson 1965; Kerfoot and DeMott 1984).

Regime shifts between different stable states may be continuous, as a consequence of a linear continuum response to gradual changes in environmental conditions, or discontinuous, when gradual changes of a driving factor might have little influence until a tipping point is reached, at which a sudden change in species composition occurs (Carpenter 2003; Suding and Hobbs 2009). Discontinuous models can also be separated between models with or without hysteresis, differing in the way they recover to the original conditions before the change. In threshold models without hysteresis, the change is reversible and follows the same pathway regardless of the direction of the environmental change (Suding and Hobbs 2009). On the other hand, in hysteresis models there are more than one equilibrium, more than one attractor, and the pathway followed before a shift is different to that followed by the reverse one (Scheffer and Carpenter 2003; Scheffer et al. 2009). Alternations between stable states, where ecosystems may have more than one equilibrium, have been widely described in ecological systems, with critical tipping points at which the system shifts between one state to the other (Scheffer and Carpenter 2003; Scheffer 2010) and several empirical evidences have been reported in a wide range of ecosystems (Schröder et al. 2005). Foreseeing tipping points to anticipate these critical transitions has been one of the main challenges in predictive ecology related to conservation ecology or climate change effects (Dakos et al. 2008; Suding and Hobbs 2009; Scheffer 2010; Scheffer et al. 2012) as well as in restoration ecology (Suding et al. 2004).

Biotic interactions with positive feedbacks, where the activity of the dominant species favours the species itself, cause a resistance to change at intermediate values of the environmental conditions (Suding et al. 2004). Positive feedbacks have been described to be a main cause of hysteresis and alternations between stable states with more than one 
equilibrium (Scheffer and Carpenter 2003; Schröder et al. 2005; Suding and Hobbs 2009). Alternative stable states theory was first developed in freshwater shallow lakes, where positive feedbacks cause a resistance to change at intermediate nutrient concentrations, explaining the alternations between nutrient-rich turbid lakes dominated by phytoplankton and more oligotrophic clear lakes dominated by macrophytes. On the one hand, macrophyte activity enhances water clarity, slowing the transition to a turbid state when the increase in nutrients is not large enough, whereas phytoplankton growth reduces light availability for benthic primary producers, preventing the recovery of a clear phase if nutrient reduction is not large enough (Scheffer et al. 1993; Scheffer 1998; Scheffer and Van Nes 2007). A similar positive feedback might operate to determine seasonal changes in species composition as those between the dominant zooplankton species in Mediterranean confined coastal lagoons. Thus, although the shifts between calanoid and Brachionus dominances seem to be driven by temperature, or by trophic state, some positive feedback produced by the own activity of these organisms might cause a resistance to change at intermediate temperature or trophic state, following the postulates of alternative stable states theory.

There are several ways to find out the existence of alternative states and to detect if a critical transition is approaching before a regime shift (Scheffer et al. 2009; Dakos et al. 2012). Some of them try to identify a slowing down in the recovery after a disturbance, measured as an increase in autocorrelation and in the variance of the state variable (Dakos et al. 2012). Other methods are based on the identification of hysteresis by comparing if the pathway in the state variable before a shift is different from that before the reverse shift (Scheffer and Carpenter 2003; Suding and Hobbs 2009). However, high-frequency data sets of the state variable, in our case the zooplankton community composition, require a huge effort of sampling and counting, which is unapproachable at medium or long term. On the other hand, technological advances during the last decades offer autonomous and accurate devices that provide high-frequency data of environmental variables such as temperature or dissolved oxygen concentration during long periods of time. Such type of sensors generate a detailed description of temporal variation in temperature and oxygen dynamics and arise as an integrative indicator of ecosystem functioning. Ecosystem responses to temperature have increased its relevance under a climate change scenario (Brucet et al. 2010, 2017; Jeppesen et al. 2010; Meerhoff et al. 2012). Moreover, fluctuations in oxygen values have been related to trophic state (Vollenweider and Kerekes 1982; Nielsen et al. 2013). A wide line of research has been developed related to the use of oxygen diel oscillations for the estimation of ecosystem metabolic rates and the analysis of their drivers in aquatic ecosystems (Staehr et al. 2010; Demars et al. 2015; Grace et al. 2015; Honti et al. 2016) as done in coastal lagoons (Carmouze et al. 1991; Howarth et al. 2014; Obrador et al. 2014; Bas-Silvestre et al. 2020).

Our aim is to investigate which forces may cause the seasonal shifts between zooplankton dominant species using a species-poor zooplankton community of a Mediterranean confined coastal ecosystem as a case study. We analysed the behaviour of some environmental variables, such as temperature or oxygen collected at high frequency, before these seasonal shifts including the detection of possible environmental thresholds. We also explored the possible existence of hysteresis in zooplankton composition, as well as possible food web-related top-down or bottom-up effects. We hypothesize that, although thresholds in some environmental variables could explain the shifts between dominant species, the own activity of the species involved and the biotic interactions established between these species facilitate the resistance to change and slow the shift.

\section{Methods}

\section{Study site}

La Pletera salt marsh contains a set of confined coastal lagoons and marshes located in Baix Ter wetlands (Girona, NE Iberian Peninsula), separated from the sea almost all the year and with no continuous freshwater supplies (Fig. 1). Water level fluctuations are strong, as it is characteristic of Mediterranean aquatic ecosystems (Quintana et al. 1998b; Alvarez-Cobelas et al. 2005; Beklioglu et al. 2007). Its hydrology is based on a flooding-confinement pattern which, in turn, determines nutrient dynamics and species composition in these habitats (Quintana et al. 1998a; Badosa et al. 2006). Flooding events are sudden, usually coinciding with sea storms or intense rainfalls, followed by long periods of confinement, with no surface water inputs but with important subsurface or groundwater inputs (Menció et al. 2017; Casamitjana et al. 2019). During confinement, water level decreases and salinity increases due to evaporation, causing the accumulation of nutrients and organic matter (Badosa et al. 2006; López-Flores et al. 2006; Quintana et al. 2018). In the 1980s, La Pletera salt marsh was affected by building works for a residential estate. To recover the ecological functioning of this coastal ecosystem, two Life Nature restoration projects were developed in the area (Life Ter VellPletera, LIFE99 NAT/E/006386, between 1999 and 2003 and Life Pletera, LIFE13 NAT/ES/001001, between 2014 and 2018). During the works of these restoration projects the remaining urban features (promenade, accesses, filling material, breakwaters, and debris) were dismantled and substituted by several confined coastal lagoons surrounded by 


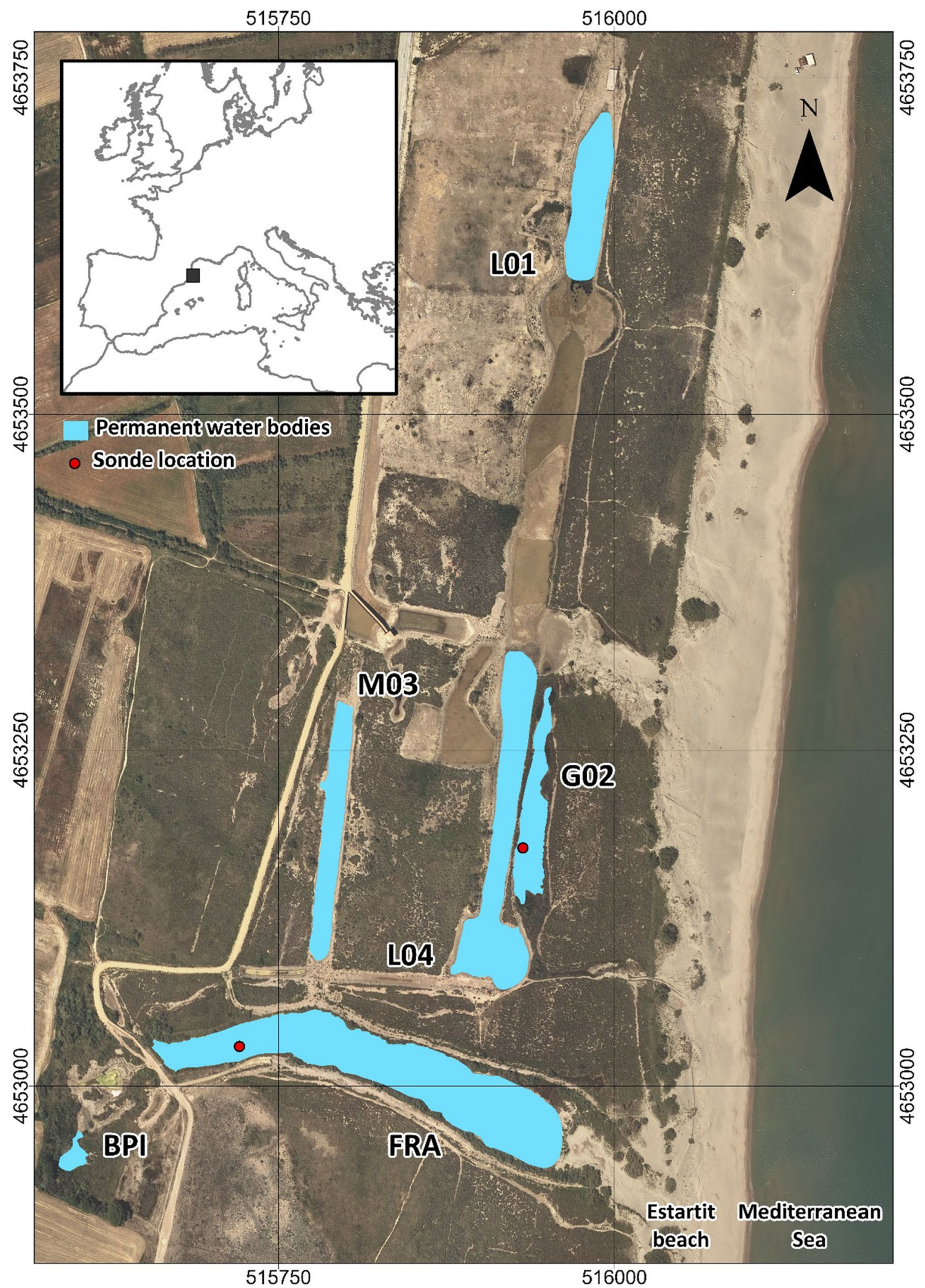

Fig. 1 Map of the study area with the location of the lagoons studied. Adapted from Cabrera et al. (2019) and Bas-Silvestre et al. (2020). BPI and FRA, natural lagoons; lagoons with a number are artificial 
the corresponding salt marsh vegetation. More details about these projects can be found at www.lifepletera.com.

\section{Sampling procedure and high-frequency measurements}

We took advantage of the water quality monitoring program developed during the Life Pletera project, from 01/10/2014 (from here on, day 1 of the study period) to 13/06/2018 (day 1352). The monitoring was done in six permanent water bodies (Fig. 1): two natural ones (FRA and BPI), one created in 2002 during the first restoration project (G02), and three new ones (L01, L04 and M03), created in 2016 during the second restoration project (around day 500). Some environmental variables of the lagoons studied are listed in Table S1. Phytoplankton chlorophyll-a was collected monthly by filtering a known volume of the lagoon water (usually $500 \mathrm{~mL}$ ) through a Whatman GF/F filter and conserved frozen until analysis. The chlorophyll-a concentrations were estimated by high-performance liquid chromatography (HPLC) following Zapata et al. (2000) and López-Flores et al. (2006).

Zooplankton samples were collected monthly as part of the monitoring program. A total volume of at least $10 \mathrm{~L}$ was taken with a plastic pot of $250 \mathrm{~mL}$ from different parts of the lagoon (at least 40 points randomly distributed) up to a maximum depth of $50 \mathrm{~cm}$, trying to integrate as much as possible the entire lagoon surface. $5 \mathrm{~L}$ of this water was filtered in situ through a $50 \mu \mathrm{m}$ net and fixed in $4 \%$ formalin. The organisms in these samples were identified and counted at the lowest taxonomical level possible without specimen manipulation. In the case of copepods, because immature stages can hardly be distinguished at species level, we grouped them in the counts at order level as calanoids, cyclopoids or harpacticoids. To identify the species present in the lagoons, some additional samples were quarterly collected using a $20 \mathrm{~cm}$ dip net (mesh size $250 \mu \mathrm{m}$ ) to attain high concentrations of copepod adults and at least 25 individuals of each copepod order were dissected for species identification. For each taxon found in the $50 \mu \mathrm{m}$ counts, we measured 25 individuals to estimate the organisms' body size and biomass (dry weight). Crustacean biomass was estimated from the allometric relationship between weight and body length (Malley et al. 1989). Rotifer and ciliate biomass was calculated by converting the volume into dry weight (Ruttner-Kolisko 1977; Putt and Stoecker 1989). See Cabrera et al. (2019) for details on zooplankton counting and biomass estimations. Flooding patterns and zooplankton composition do not differ substantially between existing and newly created lagoons (Cabrera et al. 2019).

Fish surveys were performed every three months, between 13/07/2016 (day 652) and 13/06/2018 (day 1352) using unbaited fyke nets. Theses passive fishing devices consisted of a semicircular entrance with one funnel leading to one chamber, surrounded by netting with small mesh $(3.5 \mathrm{~mm})$. Each fyke net had a single net wind at the entrance and was fixed to the bottom using two iron stakes. We chose this sampling method because of its versatility and low both size and species selectivity in this kind of habitats (Clavero et al. 2006). Traps were placed for 1 day $(\sim 24 \mathrm{~h})$ in the margin of the lagoon with the net wind facing outside the water to redirect swimming fishes towards the entrance. Six traps were placed in each lagoon, except in BPI, where only three traps were placed, because of its small size. Captured fish were identified to species level, counted in situ and up to 100 specimens per trap of each species were measured for total length $( \pm 1 \mathrm{~mm})$ and released at the same sampling point. Fish biomass was estimated from length-weight regressions (Andreu-Soler et al. 2006; Verdiell-Cubedo et al. 2006). Fish abundances (in biomass units) were counted as grams captured per unit effort (CPUE), representing the weight of fish captured in a trap per hour. Nine fish species were captured throughout the study period, with Aphanius iberus (69\% of total fish biomass) and Gambusia holbrooki (13\%) being the most abundant species, captured in all the lagoons. Mugil cephalus, Atherina boyeri, and Anguila anguila were also present. Other fish species were only occasionally captured, together representing less than $0.15 \%$ of fish captures.

In two of the water bodies, FRA (natural lagoon) and G02 (artificial lagoon created in 2002), a MiniDOT oxygen probe (PME, USA) was installed on 9 July 2015, at the deepest part of the lagoon (Fig. 1). The probe was suspended from a buoy at $30 \mathrm{~cm}$ depth. This probe provided 10-min frequency data of temperature and oxygen concentration (144 measures per day). The oxygen sensor has a resolution of $0.01 \mathrm{mg} / \mathrm{L}$ with an accuracy of $\pm 5 \%$, and the temperature sensor has a resolution of $0.01{ }^{\circ} \mathrm{C}$ with an accuracy of $0.1^{\circ} \mathrm{C}$. More details about the oxygen measurements and the resulting ecosystem metabolism estimations in these lagoons are found in Bas-Silvestre et al. (2020).

Regarding oxygen, we measured how different the oxygen concentration is from $100 \%$ saturation using the expression proposed by Vollenweider et al. (1998) for the evaluation of trophic state in coastal lagoons:

$\mathrm{aD} \% \mathrm{O}=\left|100-\% \mathrm{O}_{2}\right|$,

where $\mathrm{aD} \% \mathrm{O}$ is the absolute percent deviation from $100 \%$ dissolved oxygen saturation. Values of $\mathrm{aD} \% \mathrm{O}$ close to 0 represent oxygen saturation close to $100 \%$, while high $\mathrm{aD} \% \mathrm{O}$ values indicate oxygen oscillations far from the $100 \%$ saturation, either above (i.e. supersaturation) or below (undersaturation). 


\section{Detecting shifts and their possible causes}

To identify the shifts between dominant species, we used zooplankton species relative abundance (in biomass) of the monthly sampling dates. We defined a shift when these two conditions were met: (1) there was an increase $>50 \%$ of the relative abundance of a single species and (2) this increased value was persistent for at least 3 months (i.e. three consecutive sampling dates). Thus, we did not consider as a shift any transitory increase in a species dominance unless it was stable for at least 3 months.

To analyse the possible factors affecting the shift between dominant species, we performed the following different analyses, summarized in Fig. 2.
1. Potential thresholds before a shift (Fig. 2A): we observed the 120 days before a shift took place and analysed the trend of the daily averages of temperature and $\mathrm{aD} \% \mathrm{O}$ to identify potential discontinuous thresholds the days close to the shift, that is, when a short change in environmental conditions causes a sudden change in composition (Suding et al. 2004; Suding and Hobbs 2009). We took 120 days before a shift to exclude previous reverse shifts in the analysis, as the period between two consecutive shifts is always $>120$ days. The day $=$ 0 was set as the time when the shift was consolidated according to the criteria of zooplankton species dominances described above. Since the zooplankton sample frequency was monthly, the exact moment of a given
Fig. 2 Conceptual summary of the main possible drivers causing a shift between dominant species. A A threshold (dashed line) in an environmental variable not exceeded during the last days before a shift takes place (arrow). $\mathbf{B}$ and $\mathbf{C}$ Trajectories in environmental conditions before species shifts; $\mathbf{B}$ shows the same pathway the days before a shift to a species dominance than that before its reverse shift; $\mathbf{C}$ a different pathway before a shift to a species dominance than that before its reverse shift. D Bottom-up positive relationship between the amount of resources and the zooplankton total biomass (or the biomass of one of the dominant species). E Top-down control causing a cascading negative relationship between the fish biomass and the zooplankton biomass (or the biomass of one of the dominant species). F hysteresis, shown by differences in environmental variables when the state shifts between each dominant species

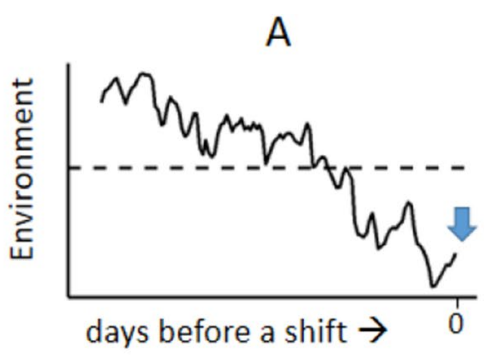

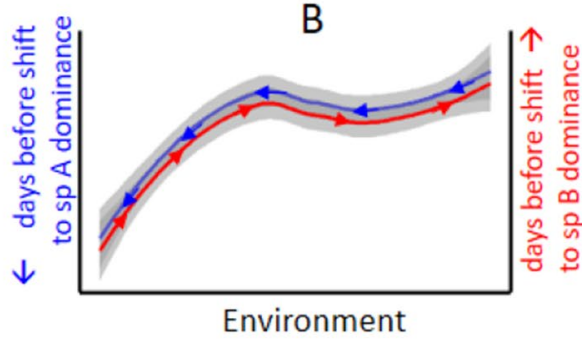

D

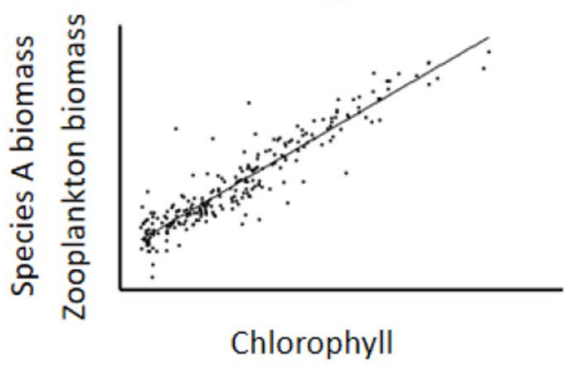

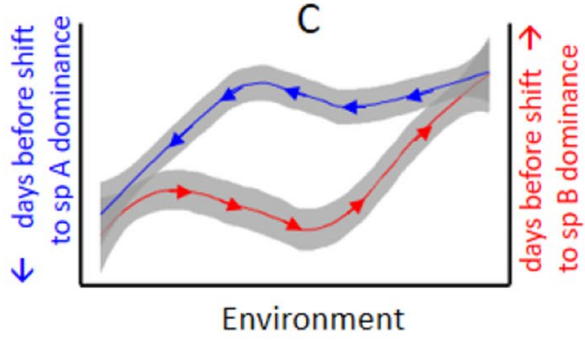

E

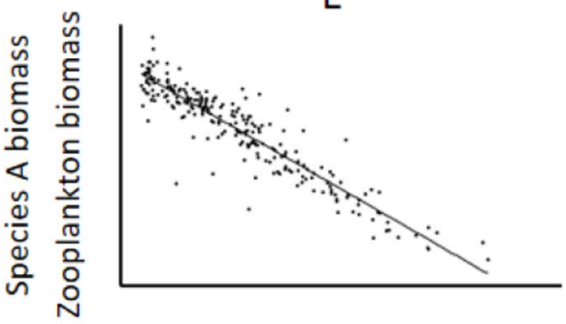

Fish biomass

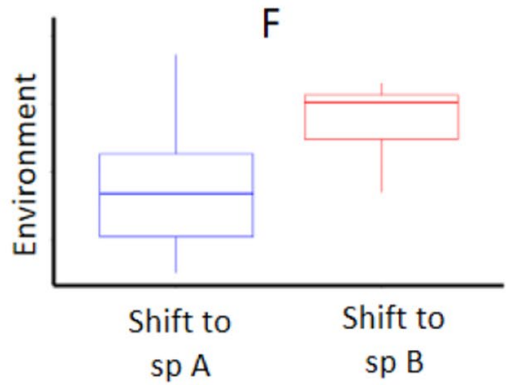


shift must take place sometime between the days -30 and -1 .

2. Pathways of environmental variables before a shift and its reverse (Fig. 2B, C): we compared the trajectories of the environmental variables during the 120 days before a shift with those before the reverse shift. We investigated if the recovery of a change in one direction of environmental variables was reversible in the opposite direction and through the same pathway (Fig. 2B) or, on the other hand (Fig. 2C), the recovery followed a very different pathway. We compared the opposite pathways by means of generalized additive model (GAM) analyses using the daily average of $\mathrm{aD} \% \mathrm{O}$ or temperature as a response variable and the number of days before the shift as the continuous variable. We performed a Gaussian GAM model using a LOESS smoothing with a span of 0.5.

3. Bottom-up or top-down forces (Fig. 2D, E): we performed several linear regressions using the chlorophyll-a concentration as explanatory variable and the zooplankton biomass or the biomass of the dominant species as response variables (Fig. 2D) to explore if there were possible bottom-up effects causing the shifts (McQueen et al. 1986). To account for cascading top-down forces (Carpenter et al. 1985; McQueen et al. 1986), we used fish biomass as explanatory variable (Figure 2E). All variables were log-transformed. We also compare the biomass of the different trophic levels (chlorophyll-a, zooplankton and fish biomass) within periods dominated by different species by means of a one-way ANOVA. Moreover, thanks to the absence of fish in newly created lagoons, immediately after creation, we compare the behaviour of the shifts under fish and fishless conditions.

4. Hysteresis (Fig. 2F): we searched for empirical evidence of hysteresis in the response to slow increases and subsequent decreases in the selected high-frequency environmental variables, temperature and $\mathrm{aD} \% \mathrm{O}$. If there is full hysteresis, values of the environmental variable before a shift should be different from the values before the reverse one (Scheffer and Carpenter 2003; Suding and Hobbs 2009). We compared the values of temperature and $\mathrm{aD} \% \mathrm{O}$ on the days close to a shift (15 days) with those values of the same variable on the days close to the reverse shift. We did the comparison with standardized values of temperature and $\mathrm{aD} \% \mathrm{O}$ (by subtracting the mean and dividing by the standard deviation), so that we could compare the amount of the possible differences between variables. Because our precision in the identification of the shift timing was 30 days, to avoid including data once the shift had already occurred (which would increase the differences between a shift and its reverse), we discarded for the comparison the data of the 30 days before the shift (days -30 to -1 ), that is, we used the data of the days -45 to -31 .

All the calculations and statistical analyses were performed in R-3.5.3. software (R Development Core Team 2019).

\section{Results}

\section{Detecting shifts}

Two different stable situations alternated in zooplankton composition in La Pletera lagoons: Brachionus dominated in summer and calanoid copepods in winter (Fig. 3A, B). Brachionus specimens belonged almost exclusively to $B$. gr. plicatilis. B. urceolaris appeared in only two samples and represented less than $2 \%$ of total zooplankton biomass. Regarding calanoid copepods, from the adults examined, 87\% were Eurytemora velox, but other calanoid species such as Acartia clausii and other undetermined Acartia were also found. Shifts between calanoid and Brachionus situations were sudden and intermediate situations usually did not last more than 1 month (Fig. 3A, B). Other zooplankton species, such as some ciliates or some rotifers of the genus Synchaeta, occasionally achieved dominances $>50 \%$, but these events were short-lived, never longer than 2 months. Similar zooplankton dominances were found in the different water bodies, both in natural and newly created ones (Fig. S1). Eight different shifts in FRA lagoon and six in G02 lagoon were identified during the study period (Table 1), with changes in the proportion of the dominant species reaching between 70 and close to $100 \%$ of the resulting biomass of the dominant species (Table 1). Although the shift to Brachionus occurred in spring or summer and the shift to calanoids in autumn or winter, the timing of the shift was highly variable among years. Some shifts did not coincide in time between the two lagoons (Table 1).

During Brachionus situations, temperature was high (mean $\left.=25.0{ }^{\circ} \mathrm{C} ; \mathrm{sd}=4.31\right)$ and oxygen saturation oscillated strongly (mean \% saturation $=63.8 ; \mathrm{sd}=81.6$; mean $\mathrm{aD} \% \mathrm{O}=81.3 ; \mathrm{sd}=37.0)$, with day values reaching $>200 \%$ and night values dropping to $<5 \%$. During calanoid situations, the temperature was lower $\left(\right.$ mean $\left.=12.7^{\circ} \mathrm{C} ; \mathrm{sd}=5.26\right)$ and oxygen saturation had lower oscillations usually closer to $100 \%$ saturation (mean $\%$ saturation $=63.2 ; \mathrm{sd}=48.4$; mean $\mathrm{aD} \% \mathrm{O}=47.3$; $\mathrm{sd}=38.2$ ), with fewer periods with oxygen saturation close to anoxia (Fig. 3C-F).

\section{Possible causes of shifts}

1. Potential thresholds before a shift: Fig. 4 shows the daily averages of temperature and $\mathrm{aD} \% \mathrm{O}$ the days before a 

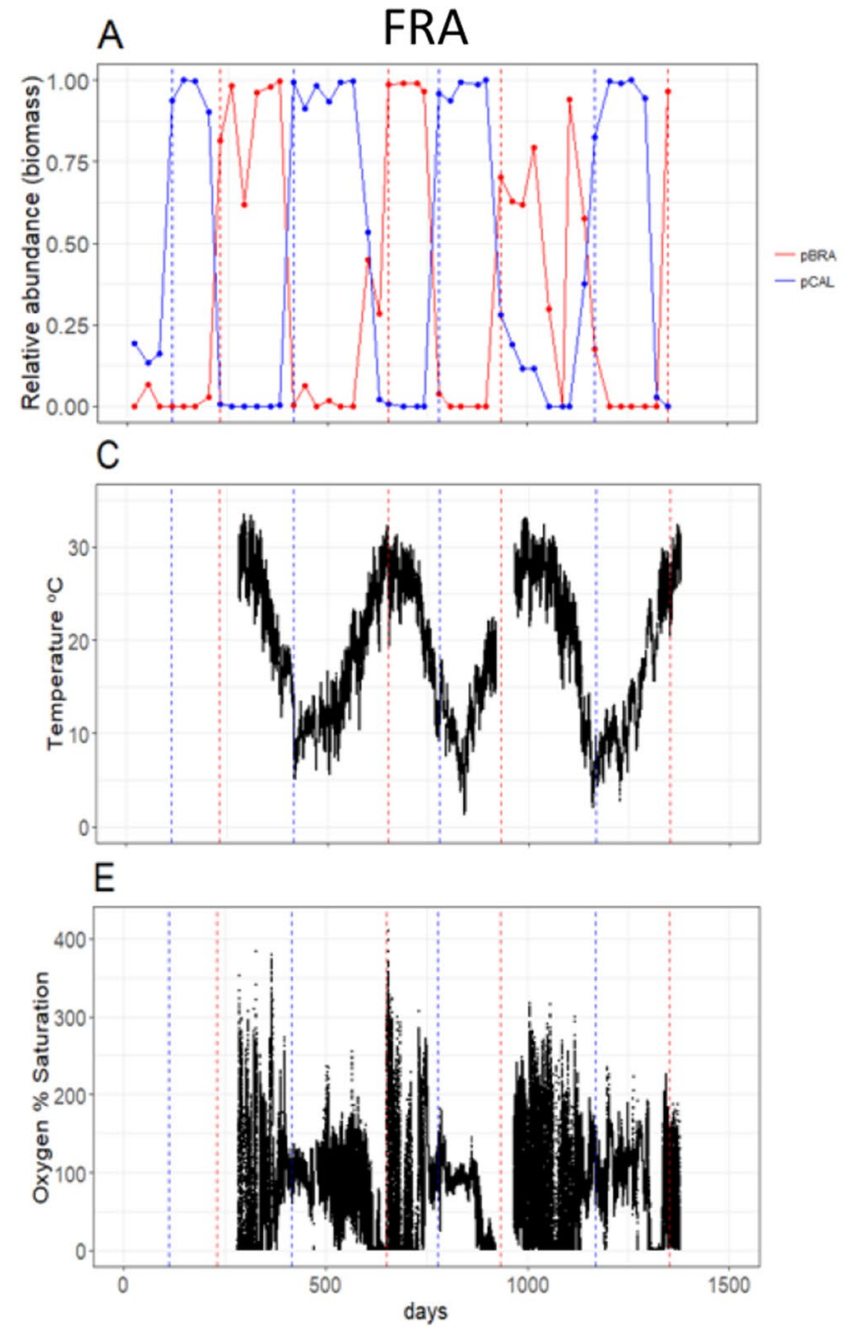

Fig. 3 Relative abundance (biomass units) of calanoid copepods (pCAL, blue) and Brachionus (pBRA, red) in monthly samples (plots $\mathbf{A}$ and $\mathbf{B}$ ) of two water bodies of La Pletera salt marshes from $1 / 10 / 2014($ day $=1)$ to $13 / 06 / 2018($ day $=1352)$. Plots $\mathbf{C}$ and $\mathbf{D}$, 10-min frequency variation in temperature; plots $\mathbf{E}$ and $\mathbf{F}, 10$-min fre-

shift to calanoids or Brachionus took place. Daily average temperature never exceeded $19^{\circ} \mathrm{C}$ in the last 20 days, nor exceeded $21.5^{\circ} \mathrm{C}$ in the last 40 days, before a shift to calanoids. $\mathrm{aD} \% \mathrm{O}$ values were usually lower than 60 in the last 40 days before a shift to calanoids, indicating average oxygen saturation close to $100 \%$, but with some exceptions ( $15 \%$ of the last 40 days with daily average $\mathrm{aD} \% \mathrm{O}>60$ ). The 40 days before a shift to Brachionus were characterized by temperatures higher than $19^{\circ} \mathrm{C}$ (except all the days before shift 6 and 4 days before shift 8 ) and $\mathrm{aD} \% \mathrm{O}$ values higher than 80 (except $22 \%$ of the last 40 days with daily average $\mathrm{aD} \% \mathrm{O}<60$ ).

2. Pathways of environmental variables before a shift and its reverse: We compared the pathways followed by the environmental variables (temperature and $\mathrm{aD} \% \mathrm{O}$ ) on the
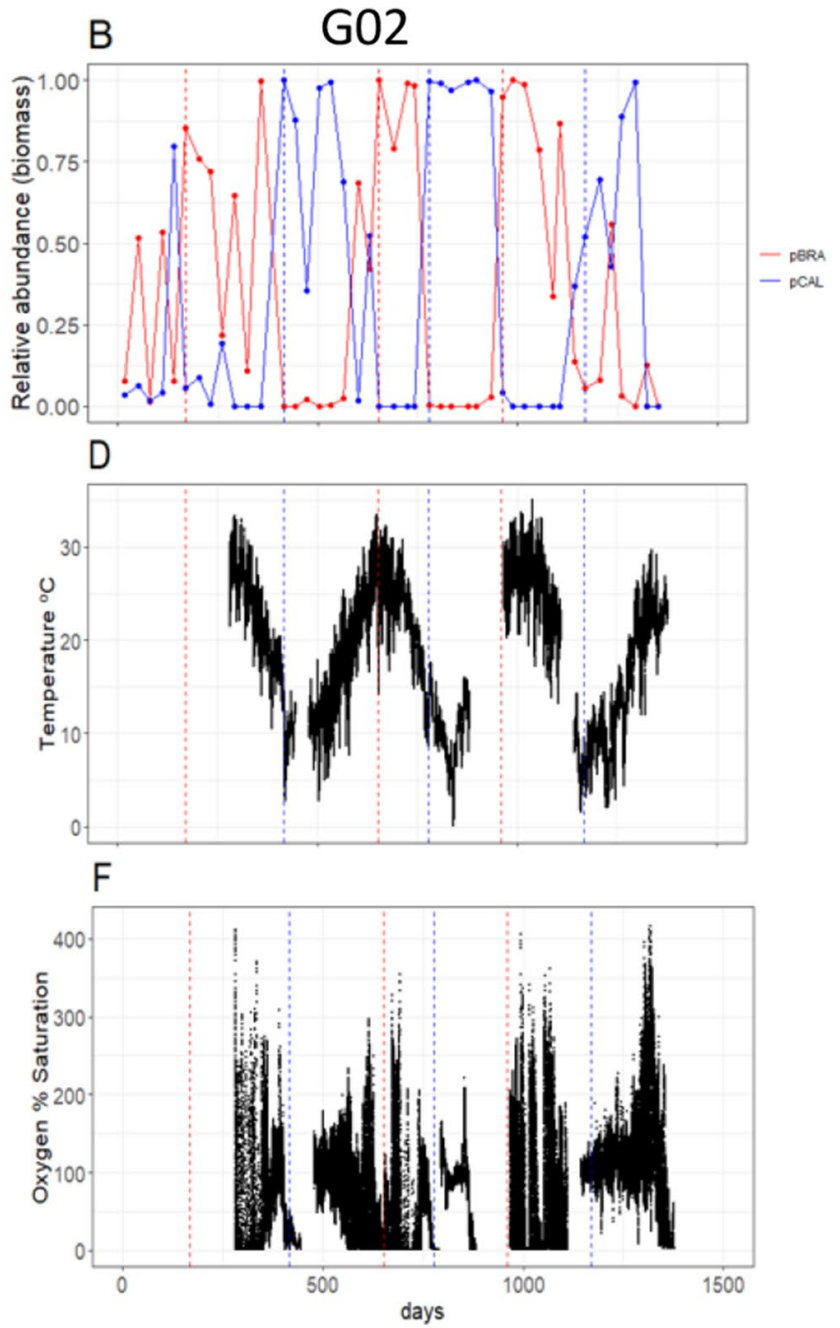

quency variation in $\%$ of oxygen saturation. Water bodies are FRA (plots A, C and E) and G02 (plots B, D and F). Dashed vertical lines indicate the shifts to a calanoid dominance (blue lines) or to a $\mathrm{Bra}$ chionus one (red lines) listed in Table 1

days before the shift to calanoids with those followed before the reverse shift to Brachionus. Pathways were significantly different for both temperature and $\mathrm{aD} \% 0$ (Fig. 5, Table 2). Differences in the pathways between a shift and its reverse were lower in temperature than in $\mathrm{aD} \% \mathrm{O}$ values. Trajectories in temperature were rather similar, while trajectories in $\mathrm{aD} \% \mathrm{O}$ before the shift to Brachionus were steeper and occurred earlier than before the reverse shift to calanoids (Fig. 5).

3. Top-down vs bottom-up forces: We found higher zooplankton biomass and lower chlorophyll-a concentrations in calanoid situations than in Brachionus situations (Table 3). Fish biomass was not significantly different. Regarding biomass ratios, during calanoid situations, there was a lower amount of chlorophyll-a per unit of 
Table 1 Identification of the shifts plotted in Fig. 3

\begin{tabular}{|c|c|c|c|c|c|}
\hline Lagoon & \# Shift & Date & Days & Shift to & Change in proportion \\
\hline FRA & $1 *$ & $20 / 01 / 2015$ & 112 & CAL & $0.16 \rightarrow 0.93$ \\
\hline FRA & $2 *$ & $19 / 05 / 2015$ & 231 & BRA & $0.02 \rightarrow 0.82$ \\
\hline FRA & 3 & $19 / 11 / 2015$ & 415 & CAL & $<0.01 \rightarrow 0.99$ \\
\hline FRA & 4 & $13 / 07 / 2016$ & 652 & BRA & $0.29 \rightarrow 0.99$ \\
\hline FRA & 5 & $16 / 11 / 2016$ & 778 & CAL & $<0.01 \rightarrow 0.96$ \\
\hline FRA & $6^{*}$ & $19 / 04 / 2017$ & 932 & BRA & $<0.01 \rightarrow 0.70$ \\
\hline FRA & 7 & $11 / 12 / 2017$ & 1168 & CAL & $0.37 \rightarrow 0.82$ \\
\hline FRA & $8 *$ & $13 / 06 / 2018$ & 1352 & BRA & $<0.01 \rightarrow 0.97$ \\
\hline G02 & $12 *$ & $18 / 03 / 2015$ & 169 & BRA & $0.07 \rightarrow 0.85$ \\
\hline G02 & 13 & $19 / 11 / 2015$ & 415 & CAL & $<0.01 \rightarrow>0.99$ \\
\hline G02 & 14 & $13 / 07 / 2016$ & 652 & BRA & $0.42 \rightarrow>0.99$ \\
\hline G02 & 15 & $16 / 11 / 2016$ & 778 & CAL & $<0.01 \rightarrow 0.99$ \\
\hline G02 & $16^{*}$ & $17 / 05 / 2017$ & 960 & BRA & $0.02 \rightarrow 0.95$ \\
\hline G02 & 17 & $11 / 12 / 2017$ & 1168 & CAL & $0.37 \rightarrow 0.82$ \\
\hline \multicolumn{6}{|l|}{ \# Shift } \\
\hline 1 & \multicolumn{5}{|c|}{$\begin{array}{l}\text { Increase in CAL proportion up to } 0.5 \text { in G02, but starting } \\
1 \text { month later than FRA and not stable (only } 1 \text { month } \\
\text { long; not considered a shift in G02) }\end{array}$} \\
\hline 2,12 & \multicolumn{5}{|c|}{$\begin{array}{l}\text { Increase in BRA proportion starting in FRA } 2 \text { months } \\
\text { later than in G02 }\end{array}$} \\
\hline 6,16 & \multicolumn{5}{|c|}{$\begin{array}{l}\text { Increase in BRA proportion starting in FRA } 1 \text { month } \\
\text { before than in G02 }\end{array}$} \\
\hline 8 & \multicolumn{5}{|c|}{$\begin{array}{l}\text { Increase in BRA proportion up to } 0.5 \text { in } \mathrm{G} 02 \text {, but not } \\
\text { stable (only } 1 \text { month long; not considered a shift in G02) }\end{array}$} \\
\hline
\end{tabular}

The change in proportion observed of the dominant species is also listed. Shifts $1-8$ belong to FRA water body; shifts $12-17$ belong to G02. Ten-minute frequency temperature and oxygen data are available since day 282. "Days" correspond to the number of days after $1 / 10 / 2014($ day $=1)$, also represented in the $x$ axes of Figs. 3 and 6 and $\mathrm{S} 1$

*The shifts with no coincidence in time in both lagoons are indicated

zooplankton biomass and a higher amount of zooplankton per unit of fish biomass. Regressions between the biomass of the different trophic levels were not significant, both overall and within situations, with the only exception of the overall relationship between zooplankton biomass and chlorophyll-a concentration, which was negative, with a very low $r^{2}$ (Table 4$)$. The same was found for the log-ratio between the biomass of calanoids and Brachionus.

Since some of the lagoons were newly created during the study period (approximately in day $=500$ ), they did not have fish during the first year. When we compared the patterns of shifts between calanoid and Brachionus situations, they were similar both under presence or absence of fish. The moments and intensity of shifts were similar between a new fishless lagoon and a natural one with fish during the same year, as well as between two different years (the first one fishless, the second with fish) in the same newly created lagoon (Fig. 6).
4. Hysteresis: A strong difference between the values of temperature and $\mathrm{aD} \% \mathrm{O}$ before a shift and those of the same variable before the reverse shift might indicate hysteresis (see methods). In this sense, average temperature was $18.1{ }^{\circ} \mathrm{C}$ and average $\mathrm{aD} \% \mathrm{O}$ was 53.6 before a shift to calanoids. Before a shift to Brachionus, the values were 21.2 and 86.9. Differences in temperature standardized values were significant $\left(F_{1,130}=68.72\right.$, $p<0.0001$ ), but with a high overlap in percentiles. Differences in $\mathrm{aD} \% \mathrm{O}$ standardized values were also significant $\left(F_{1,130}=27.27, p<0.0001\right)$ and with less overlap (Fig. 7). The magnitude of the difference in the standardized average value before both shifts was lower for temperature $(=0.50)$ than for $\mathrm{aD} \% \mathrm{O}(=1.01)$.

\section{Discussion}

The dominances in zooplankton composition in La Pletera salt marshes respond differently to changes in temperature or oxygen saturation. Our results show a possible threshold in temperature close to $19{ }^{\circ} \mathrm{C}$ (daily average), causing the shift between the low-temperature calanoid-dominated assemblage and the high-temperature Brachionus dominated one. Although $\mathrm{aD} \% \mathrm{O}$ values are usually low in calanoid situations and high in Brachionus ones (indicating oxygen percentages of saturation close to and far from $100 \%$, respectively), $\mathrm{aD} \% \mathrm{O}$ values are highly variable when a shift is approaching and we do not identify any threshold in $\mathrm{aD} \% \mathrm{O}$ in the immediate days before a shift. Moreover, there is some covariation between temperature and oxygen oscillations, so that there are not situations with low temperature and high oxygen oscillations. This is expected in confined ecosystems, where there is a lack of external inputs most of the year and where internal processes dominate over external loadings (Gamito et al. 2005; Glibert et al. 2010). Thus, oxygen dynamics depends more on system metabolism, which in turn is dependent on temperature (Obrador and Pretus 2010, 2012; Bas-Silvestre et al. 2020), rather than on physical processes related to surface water inputs, which are especially low during confinement conditions (Menció et al. 2017; Casamitjana et al. 2019).

As described before (Badosa et al. 2006; Cabrera et al. 2019), Eurytemora velox is the dominant species of calanoid assemblages, a species which is close to its southern limit of distribution in La Pletera salt marshes (Gaviria and Forró 2000) and this may explain its high sensitivity to temperature increases. In the Mediterranean coast of Iberian Peninsula, E. velox presence has not been reported in brackish or saline marshes further south of Baix Ter wetlands, where La Pletera is located. Other calanoids, such as Calanipeda 

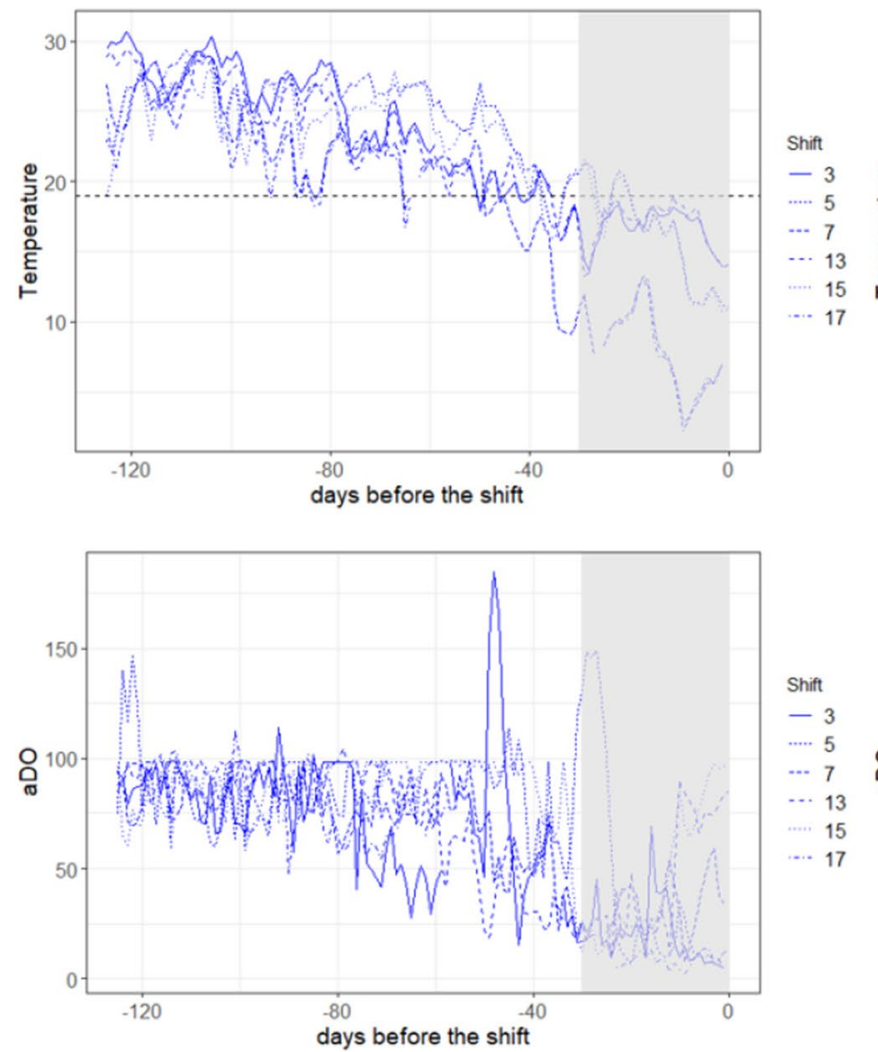

Fig. 4 Daily averages (from 144 10-min frequency measurements) of water temperature and $\mathrm{aD} \% \mathrm{O}$ before a shift to a calanoid situation (blue plots) or to a Brachionus situation (red plots). Horizontal dashed line in temperature plots represents a daily average temperature of $19^{\circ} \mathrm{C}$, never exceeded the last 20 days before a shift to calanoids. The $x$ axis represents the number of days before the shift takes place, where 0 represents the moment when the shift has been consolidated (change in the dominant species, as described in methods).

aquaedulcis dominate in these southern marshes (Comín et al. 1987; Anton-Pardo and Armengol 2012, 2014). In nearby temporary or semipermanent salt marshes E. velox and $C$. aquaedulcis coexist and alternate as the dominant species, with $E$. velox dominating under conditions of low temperatures and C. aquaedulcis under higher ones (Quintana et al. 1998a; Brucet et al. 2005a). Calanoid copepods are substituted by other species under conditions of high confinement when lagoons are close to desiccation, with Brachionus gr. plicatilis being the dominant species under more eutrophic conditions (Quintana et al. 2006). Brachionus situations in La Pletera were almost exclusively composed by $B$. gr. plicatilis, a species widely distributed in Mediterranean coastal waters (Miracle et al. 1987; Quintana et al. 1998a; Brucet et al. 2005a; Anton-Pardo and Armengol 2014), with a great tolerance to high temperatures and long periods of anoxia (Esparcia et al. 1989).

Fish top-down control has no effect on zooplankton shifts in La Pletera salt marshes, since the same shift pattern have
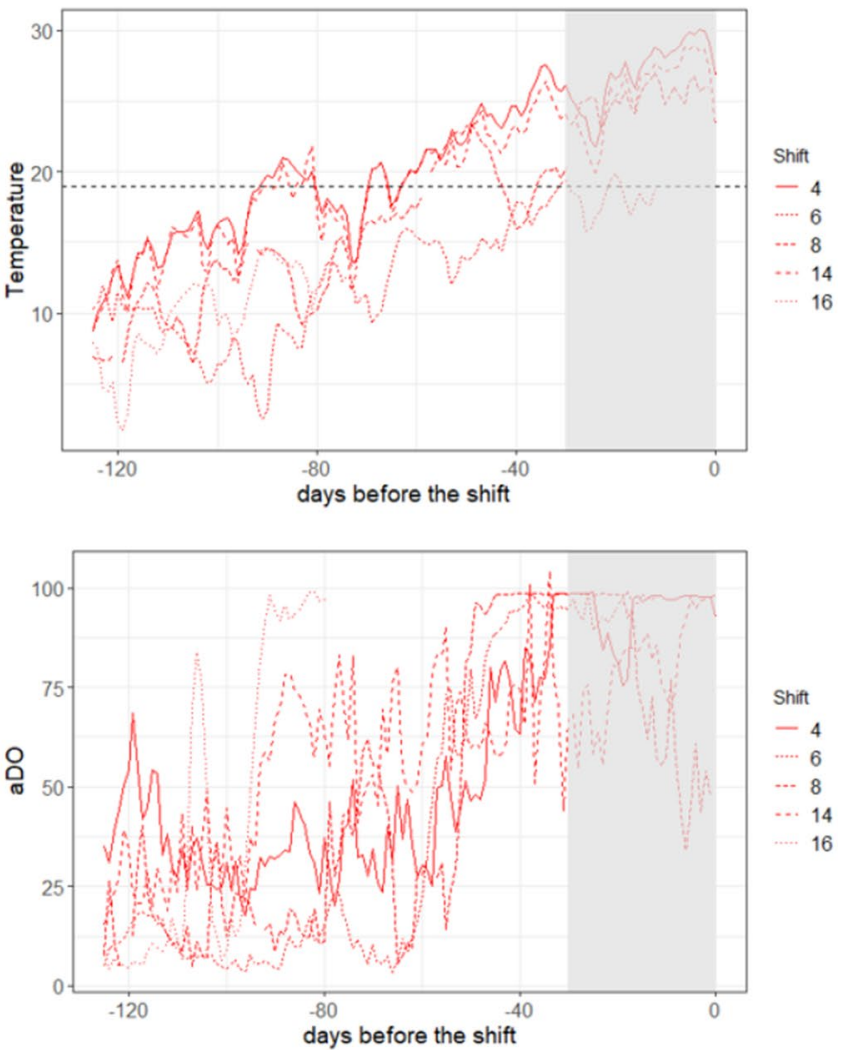

Because the frequency of the zooplankton sampling was monthly, the shift must take place during the days within the grey band (30 days wide). Each point line represents a different shift. The number of each shift as listed in Table 1. We used 120 days before a shift to be sure that this period does not include any other anterior shift, since the shortest period between two consecutive shifts is always $>120$ (see Table 1)

been observed under fish and fishless conditions. The planktivorous cyprinodont Aphanius iberus is the most abundant species in La Pletera, reaching high densities in all the studied lagoons (Alcaraz and García-Berthou 2007; Badosa et al. 2007). Although there are some experimental evidences of the effect of $A$. iberus on zooplankton species composition using adult females that prefer big zooplankters (Compte et al. 2011), smaller fish of this species select smaller zooplankton sizes (Alcaraz and Garcia-Berthou 2007). Thus A. iberus may feed on both dominant zooplankton species, calanoids and Brachionus. Fish activity in these coastal ecosystems has been described to have more effect on zooplankton size distribution than on zooplankton species composition (Badosa et al. 2007; Compte et al. 2012). This influence of fish predation on zooplankton size distribution in aquatic ecosystems is well known (Brooks and Dodson 1965; Quintana et al 2015). No significant increases in zooplankton biomass were found with increasing chlorophyll-a concentrations, discarding possible bottom-up effects mediated by 

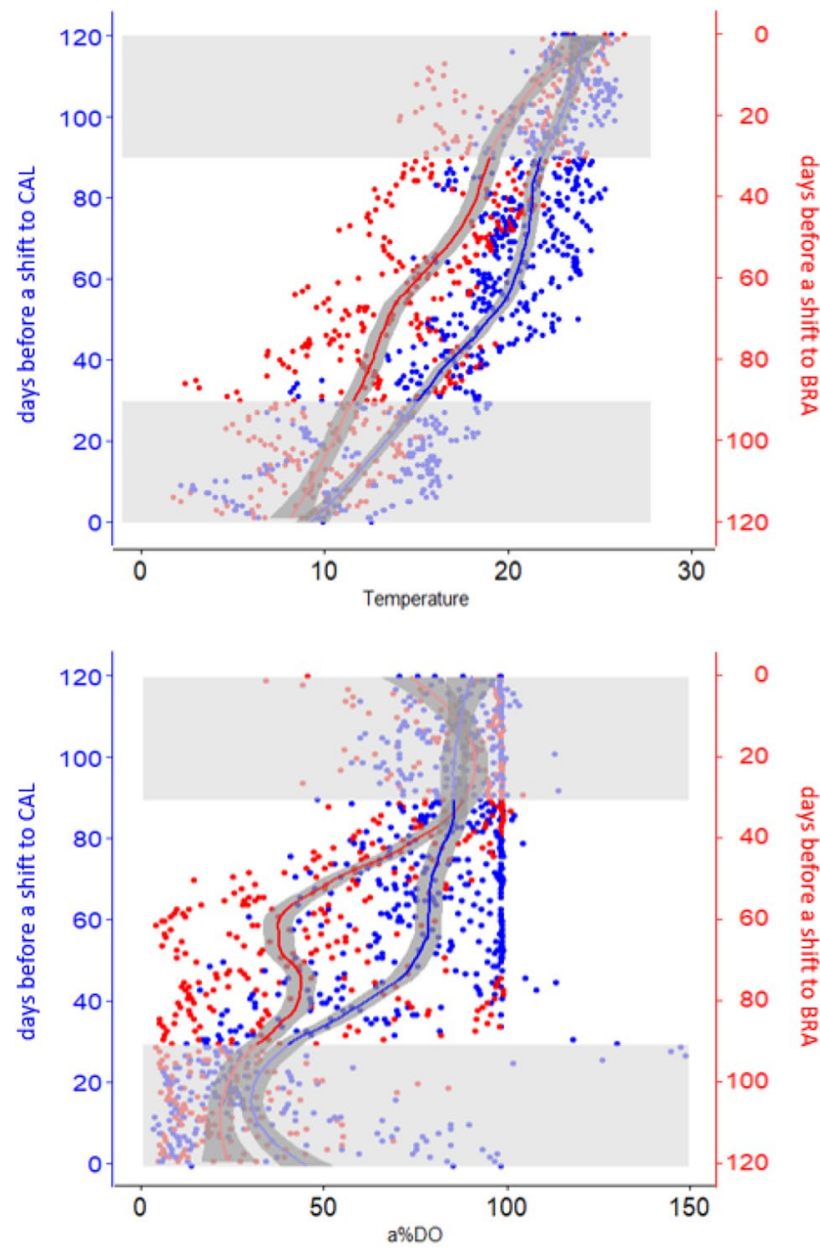

Fig. 5 GAM models showing the pathways followed by the daily averages of temperature (up) and $\mathrm{aD} \% \mathrm{O}$ (down) the last 120 days before a shift to calanoids (blue $y$ scale, line and points) and before the reverse shift to Brachionus (red $y$ scale, line and points). Data of all the shifts listed in Table 1 are included. As in Fig. 4, the shift must take place during the days within the grey band (30 days wide)

algal biomass. Bottom-up control has been described to be relevant in phytoplankton composition (Lopez-Flores et al. 2006), but our results show that its importance decreases in higher trophic levels.

Several methods based on modelling and observation of field data have been proposed to detect and anticipate critical transitions between stable states, usually related to flickering slowing down as a consequence of a reduction in resilience when a shift is approaching. Increase in the variance and in the autocorrelation in the state variable when approaching a tipping point has been used to detect such slowing downs (Scheffer et al. 2009; Dakos et al. 2012). The use of different independent methods in parallel has been suggested to identify alternative attractors, since the different methods used have different strengths and weaknesses and none of these methods is conclusive to ensure the existence of these
Table 2 Results of the GAM models in the daily average of temperature and $\mathrm{aD} \% \mathrm{O}$ in the last 120 days before a shift to calanoids or to Brachionus represented in Fig. 5

\begin{tabular}{lllll}
\hline & Estimate & Std. Error & $t$ value & $p$ \\
\hline Temperature & & & & \\
$\quad$ Adjusted $R^{2}$ & 0.73 & & & \\
Intercept & 17.5 & 0.1 & 119 & $<0.001$ \\
Factor (= shift) & 3.59 & 0.2 & 19 & $<0.001$ \\
Smooth term & 7.09 & & & $<0.001$ \\
aD\%O & & & & \\
Adjusted $R^{2}$ & 0.54 & & & \\
Intercept & 53.5 & 1 & 54 & $<0.001$ \\
Factor (=shift) & 13.6 & 1.3 & 10 & $<0.001$ \\
Smooth term & 7.91 & & & $<0.001$ \\
\hline
\end{tabular}

The factor shift indicates how many times greater is the value of the environmental variable in the shift to calanoids than in the reverse shift to Brachionus

attractors (Scheffer and Carpenter 2003). We cannot apply in our data those methods based on the oscillations of the state variable, in our case the zooplankton composition, since only monthly samples are available. The fast shift between dominant species shows that state oscillations occur at a higher frequency than the sampling. Previous studies with weekly collected samples show a relatively high turnover in zooplankton species (Quintana et al. 1998a; Brucet et al. $2005 a, b)$, even being a weekly frequency insufficient to detect flickering in zooplankton composition. Higher sampling frequencies appear to be unapproachable, unless there is some kind of automation of the sampling and counting procedure.

Detecting hysteresis is another way to identify alternations between two ecosystem states (Scheffer and Carpenter 2003; Dakos et al. 2012). In La Pletera salt marshes, differences in temperature and $\mathrm{aD} \% \mathrm{O}$ values before a shift to Brachionus are significantly higher than those found before the reverse shift to calanoids. Differences in $\mathrm{aD} \% \mathrm{O}$ are two times higher than those found in temperature values. This suggests the existence of hysteresis, more detectable with $\mathrm{aD} \% \mathrm{O}$ values, but also identifiable in temperature values. However, we have to take into account that hysteresis may fail to identify alternative attractors when the rate of change in the control factor is much faster than the response of the system (Scheffer and Carpenter 2003). This seems not to be the case in the zooplankton of the Pletera, where there is a fast turnover in zooplankton species (Quintana et al. 1998a; Brucet et al. 2005a) and a fast response to restoration actions (Cabrera et al. 2019). Differences in trajectories of environmental variables before the shift and its reverse are compatible with hysteresis. However, differences in turnover between species involved may also explain slower or faster trajectories of environmental variables before a shift, as is 
Table 3 Mean and standard deviation (in brackets) of the biomass of the different trophic levels, and of the logratios between trophic levels, in situations dominated by calanoid (CAL) and Brachionus (BRA)

\begin{tabular}{lccrrr}
\hline & CAL & BRA & \multicolumn{1}{l}{$F$} & D $f$ & \multicolumn{1}{c}{$p$} \\
\hline Chlorophyll-a $\left(\mu \mathrm{g} \cdot \mathrm{L}^{-1}\right)$ & $8.2(14.1)$ & $48.7(76.0)$ & 81.32 & 1,178 & $<0.001$ \\
Zooplankton $\left(\mu \mathrm{gDW} \cdot \mathrm{L}^{-1}\right)$ & $251.1(575.6)$ & $88.3(181.4)$ & 15.96 & 1,178 & $<0.001$ \\
Fish $(\mathrm{CPUE})$ & $3.8(6.6)$ & $9.3(18.4)$ & 1.87 & 1,67 & 0.203 \\
$\log ($ chlorophyll-a/zooplankton) & $-2.3(2.3)$ & $0.7(2.8)$ & 63.39 & 1,178 & $<0.001$ \\
$\log ($ zooplankton/fish) & $3.3(2.1)$ & $1.0(2.6)$ & 10.94 & 1,47 & 0.002 \\
\hline
\end{tabular}

Results of the ANOVA test comparing both situations are also included. CPUE, fish biomass (g) captured per unit effort (see methods). DW, dry weight

\begin{tabular}{llllllll}
\hline Response variable & Explanatory variable & Period & $r^{2}$ & Slope & $F$ & Df & $p$ \\
\hline Zooplankton & Fish & Overall & $n . s$ & & 0.32 & 1,52 & 0.577 \\
& & CAL & $n . s$ & & 0.36 & 1,22 & 0.557 \\
& & BRA & $n . s$ & & 0.35 & 1,23 & 0.559 \\
Zooplankton & Chlorophyll-a & Overall & $\mathbf{0 . 0 2}$ & $\mathbf{- 0 . 2 1 8}$ & $\mathbf{5 . 2 7}$ & $\mathbf{1 , 2 0 9}$ & $\mathbf{0 . 0 2 3}$ \\
& & CAL & $n . s$ & & 1.35 & 1,101 & 0.248 \\
& & BRA & $n . s$ & & 0.05 & 1,75 & 0.827 \\
$\log$ (calanoids/Brachionus) & Fish & Overall & $n . s$ & & 0.008 & 1,52 & 0.931 \\
$\log$ (calanoids/Brachionus) & Chlorophyll-a & Overall & $\mathbf{0 . 2 6}$ & $\mathbf{- 2 . 3 4 4}$ & $\mathbf{7 3 . 6 9}$ & $\mathbf{1 , 2 0 9}$ & $<\mathbf{0 . 0 0 1}$ \\
\hline
\end{tabular}

All data were in biomass and log transformed before regression. Significant regressions $(p<0.05)$ in bold
Table 4 Top-down

bottom-up regressions: chlorophyll-a, zooplankton and fish relationships and their differences between calanoid (CAL) and Brachionus (BRA) situations
Fig. 6 Fish biomass (black points) compared to the relative abundance of calanoid copepods (pCAL, blue) and Brachionus (pBRA, red) in a newly created lagoon (lagoon L01) after its creation about day 500. Fish biomass (log units) are in CPUE (see methods). Dashed vertical lines indicate the shifts to a calanoid dominance (blue lines) or to a Brachionus one (red lines) as defined in the methods section

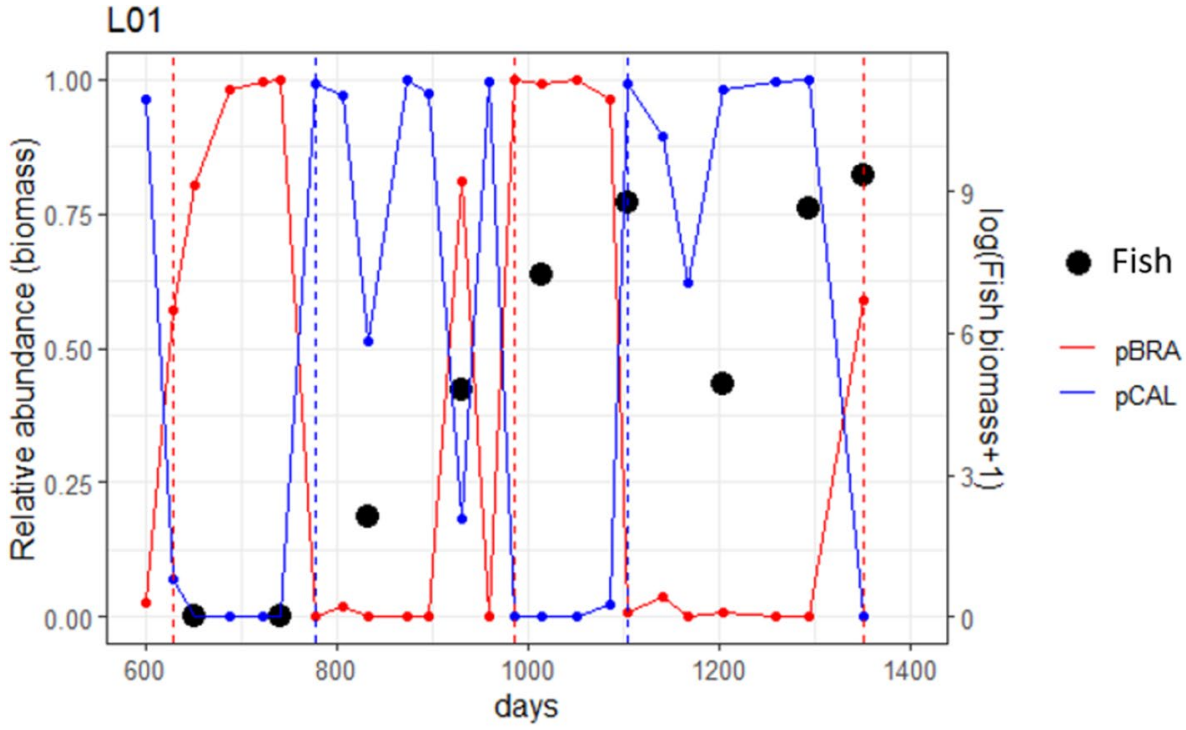

the case of $\mathrm{aD} \% \mathrm{O}$ values (Fig. 5). Brachionus has a faster life cycle compared to E. velox (James and Rezeq 1989; Nagaraj 1988 ) and this asymmetry may result in different speeds of their response to changes in environmental conditions.

Alternative equilibria between two stable states are based on positive feedbacks among species involved, where dominant species are self-reinforcing by their own activity (Scheffer et al. 1993; Scheffer and Carpenter 2003) and this means an overall negative effect between alternative dominant species as is characteristic of typical competitive interactions (Smith et al. 1975; Werner and Gilliam 1984). This is represented in minimal models as competitive coefficients of negative sign (Scheffer et al. 1993). Asymmetry in the behaviour of the ecosystem state before a shift and its reverse can also occur, considering asymmetry not only as the difference in the intensity of the competitive coefficients, but also in the sign of this interaction. In fact, trophic interactions between E. velox and B. gr. plicatilis are not limited to competition for resources. Although both species may be considered as filter feeding grazers (Pagano and Gaudy 

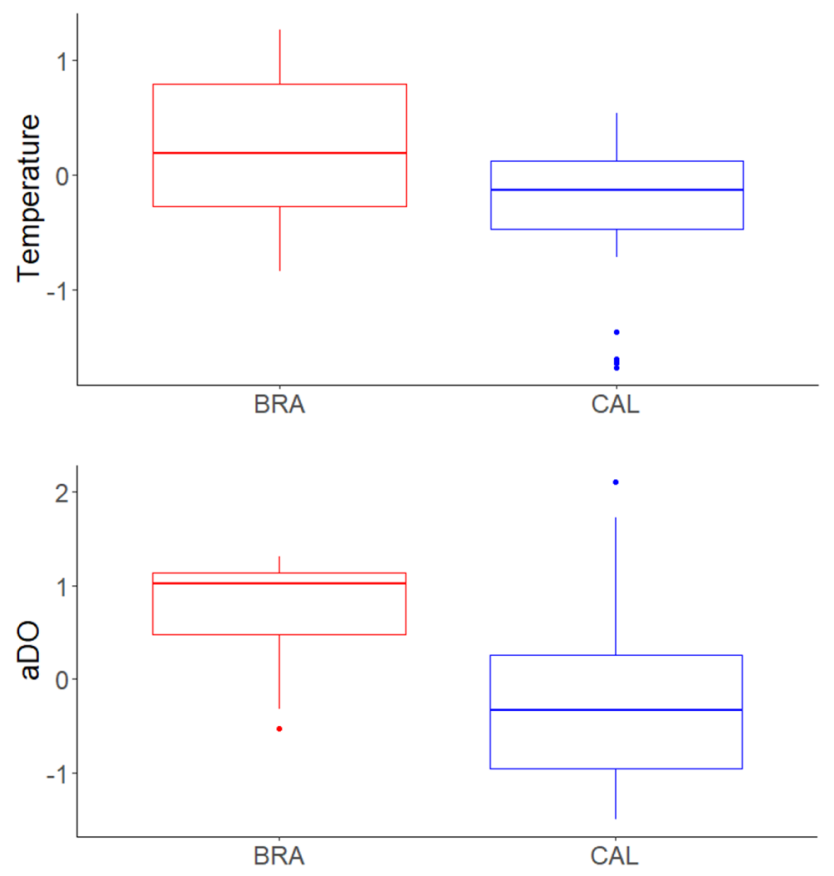

Fig. 7 Comparison of the temperature and $\mathrm{aD} \% \mathrm{O}$ values in a 15 days window before a shift to Brachionus (BRA) and before the reverse shift to calanoids (CAL). Temperature and $\mathrm{aD} \% \mathrm{O}$ data were standardized to facilitate the comparison. To be sure that we do not include data once the shift has already occurred, we discarded for the comparison the data of the last 30 days before the shift (see methods)

1986; Wallace et al. 2006), the result of the activity of each one over the other is different because of their differences in size. While $B$. gr. plicatilis mean and maximal lengths measured in our samples are 0.16 and $0.46 \mathrm{~mm}$, E. velox adults may reach more than $2 \mathrm{~mm}$ (1.26 and $2.27 \mathrm{~mm}$ mean and maximum observed lengths), thus being $E$. velox great enough to graze on $B$. gr. plicatilis. Grazing on rotifers by $E$. velox has already been reported (Monakov 1972; Williamson 1983 ) as do other calanoid copepods (Brandl 2005; Jagadeesan et al. 2017; Mzozo et al. 2019). In this context, B. gr. plicatilis growth would promote $E$. velox growth and, thus, the self-reinforcing positive feedback would appear only in $E$. velox activity. A double positive effect of prey consumption and reduced competition on predators promoting alternative stable states has already been described in theoretical frameworks dealing with intraguild predation (Polis et al. 1989). Moreover, given the complex ontogenetic development of copepods, size-based intraspecific interactions between those different development stages become especially relevant in monospecific calanoid-dominated zooplankton assemblages. Calanoids may avoid intraspecific competition by niche segregation between different development stages, leading to a size-based trophic structure (Polis et al. 1989; Ye et al. 2013; Quintana et al. 2015). There are evidences of such niche segregation in calanoid-dominating assemblages of confined salt marshes (Brucet et al. 2005b, 2008), where an increase in size diversity has been described with increasing stability or decreasing food availability (Brucet et al. 2006; Badosa et al. 2007). On the other hand, cannibalism by adults, already described in calanoids (Daan et al. 1988; Frank-Gopolos et al. 2017), may limit the development of their early stages reducing advantages of intraguild predation. The long-term stability of calanoid dominances even under decreasing water and nutrient inputs, found in confined coastal habitats (Quintana et al. 1998b; Brucet et al. 2006), suggest that direct negative effects of cannibalism, if present, should be less important than the indirect positive effects of adults grazing on rotifers or the positive effects of decreasing intraspecific competition between different development stages, thanks to a size-based trophic niche partitioning.

Regime shifts are driven by multiple causes, including trade-offs in trophic interactions and external environmental forces (Scheffer and Carpenter 2003). Understanding their patterns may help not only to predict abrupt shifts to long-term different regimes, but also to detect alternative attractors of seasonal changes, which are recurrent in plankton communities (Margalef 1978; Glibert 2016; Kenitz et al. 2017). Environmental constrictions such as those found in brackish and saline habitats may lead to speciespoor, but high functioning and structured communities (Brucet et al. 2006, 2010; Boix et al. 2008; Horváth et al. 2014). In such species-poor communities, the particular biological traits of species involved become more relevant to understand changes in system state. In monospecific assemblages, intraspecific competition becomes especially relevant and reinforces size-based interactions between the different stages of the dominant species (Polis et al. 1989; Ye et al. 2013; Quintana et al. 2015). This is the case of La Pletera where trophic interactions affecting seasonal shifts seem to be limited to the relationships between two species. In this sense, the possible sensitivity of E. velox to an increase in temperature arises as a determinant factor in alternations of zooplankton dominances and might be relevant in possible future changes mediated by climate change. An increase in the temperature might shorten the duration of E. velox dominance, favouring Brachionus. But it also might favour the appearance of other calanoid species more adapted to high temperatures, such as $C$. aquaedulcis, which is abundant in nearby salt marshes and which could reduce substantially the duration of the Brachionus situation. With the appearance of $C$. aquaedulcis, alternations between stable states would be between dominant species similar in size. In this case, probably changes in trophic state and in oxygen concentrations would become more relevant in zooplankton shifts and the system would reflect more symmetric critical transitions among stable states. 
Supplementary Information The online version contains supplementary material available at https://doi.org/10.1007/s00027-021-00824-5.

Acknowledgements Financial support was provided by the Ministerio de Economia, Industria y Competitividad (refs. CGL201786515-P and CGL2016-76024-R AEI/FEDER/UE), the Generalitat de Catalunya (ref. 2017 SGR 548) and the University of Girona (MPCUdG2016-049). We thank the two anonymous referees for their valuable suggestions and comments.

Funding Open Access funding provided thanks to the CRUE-CSIC agreement with Springer Nature.

\section{Declarations}

Conflict of interest The authors have no conflicts of interest to declare that are relevant to the content of this article.

Open Access This article is licensed under a Creative Commons Attribution 4.0 International License, which permits use, sharing, adaptation, distribution and reproduction in any medium or format, as long as you give appropriate credit to the original author(s) and the source, provide a link to the Creative Commons licence, and indicate if changes were made. The images or other third party material in this article are included in the article's Creative Commons licence, unless indicated otherwise in a credit line to the material. If material is not included in the article's Creative Commons licence and your intended use is not permitted by statutory regulation or exceeds the permitted use, you will need to obtain permission directly from the copyright holder. To view a copy of this licence, visit http://creativecommons.org/licenses/by/4.0/.

\section{References}

Alcaraz C, García-Berthou E (2007) Food of an endangered cyprinodont (Aphanius iberus): ontogenetic diet shift and prey electivity. Environ Biol Fish 78:193-207. https://doi.org/10.1007/ s10641-006-0018-0

Alvarez-Cobelas M, Rojo C, Angeler D (2005) Mediterranean limnology: current status, gaps and future. J Limnol 64:13-29. https:// doi.org/10.4081/jlimnol.2005.13

Andreu-Soler A, Oliva-Paterna FJ, Torralva M (2006) A review of length-weight relationships of fish the Segura River basin (SE Iberian Peninsula). J Appl Ichthyol 22:295-296. https://doi.org/ 10.1111/j.1439-0426.2006.00719.x

Anton-Pardo M, Armengol X (2012) Effects of salinity and water temporality on zooplankton community in coastal Mediterranean ponds. Estuar Coast Shelf Sci 114:93-99. https://doi.org/10. 1016/j.ecss.2011.08.018

Anton-Pardo M, Armengol X (2014) Aquatic invertebrate assemblages in ponds from coastal Mediterranean wetlands. Ann Limnol 50:217-230. https://doi.org/10.1051/limn/2014089

Attayde JL, Bozelli RL (1998) Assessing the indicator properties of zooplankton assemblages to disturbance gradients by canonical correspondence analysis. Can J Fish Aquat Sci 55:1789-1797. https://doi.org/10.1139/f98-033

Badosa A, Boix D, Brucet S et al (2006) Nutrients and zooplankton composition and dynamics in relation to the hydrological pattern in a confined Mediterranean salt marsh (NE Iberian Peninsula). Estuar Coast Shelf Sci 66:513-522. https://doi.org/10.1016/j. ecss.2005.10.006

Badosa A, Boix D, Brucet S et al (2007) Zooplankton taxonomic and size diversity in Mediterranean coastal lagoons (NE Iberian
Peninsula): influence of hydrology, nutrient composition, food resource availability and predation. Estuar Coast Shelf Sci 71:335-346. https://doi.org/10.1016/j.ecss.2006.08.005

Bas-Silvestre M, Quintana XD, Compte J et al (2020) Ecosystem metabolism dynamics and its environmental drivers in Mediterranean confined coastal lagoons. Estuar Coast Shelf Sci 245:106989

Batzer D, Boix D (2016) Invertebrates in freshwater wetlands: an international perspective on their ecology. Springer International Publishing

Beklioglu M, Romo S, Kagalou I et al (2007) State of the art in the functioning of shallow Mediterranean lakes: workshop conclusions. Hydrobiologia 584:317-326. https://doi.org/10.1007/ s10750-007-0577-x

Boak AC, Goulder R (1983) Bacterioplankton in the Diet of the Calanoid Copepod Eurytemora sp. in the Humber Estuary. Mar Biol 73:139-149

Boix D, Sala J, Gascón S et al (2007) Comparative biodiversity of crustaceans and aquatic insects from various water body types in coastal Mediterranean wetlands. Hydrobiologia 584:347-359. https://doi.org/10.1007/s10750-007-0579-8

Boix D, Gascón S, Sala J et al (2008) Patterns of composition and species richness of crustaceans and aquatic insects along environmental gradients in Mediterranean water bodies. Hydrobiologia 597:53-69. https://doi.org/10.1007/s10750-007-9221-z

Brandl Z (2005) Freshwater copepods and rotifers: predators and their prey. Hydrobiologia 546:475-489. https://doi.org/10.1007/ s10750-005-4290-3

Brooks JL, Dodson SI (1965) Predation, body size, and composition of plankton. Science 150:28-35. https://doi.org/10.1126/science. 150.3692 .28

Brucet S, Boix D, López-Flores R et al (2005a) Zooplankton structure and dynamics in permanent and temporary Mediterranean salt marshes: taxon-based and size-based approaches. Arch Fur Hydrobiol 162(4):535-555. https://doi.org/10.1127/0003-9136/ 2005/0162-0535

Brucet S, Boix D, López-Flores R et al (2005b) Ontogenic changes of amino acid composition in planktonic crustacean species. Mar Biol 148:131-139. https://doi.org/10.1007/s00227-005-0068-4

Brucet S, Boix D, López-Flores R et al (2006) Size and species diversity of zooplankton communities in fluctuating Mediterranean salt marshes. Estuar Coast Shelf Sci 67:424-432. https://doi.org/ 10.1016/j.ecss.2005.11.016

Brucet S, Compte J, Boix D et al (2008) Feeding of nauplii, copepodites and adults of Calanipeda aquaedulcis (Calanoida) in Mediterranean salt marshes. Mar Ecol Prog Ser. https://doi.org/ 10.3354/meps07225

Brucet S, Boix D, Gascón S et al (2009) Species richness of crustacean zooplankton and trophic structure of brackish lagoons in contrasting climate zones: North temperate Denmark and Mediterranean Catalonia (Spain). Ecography 32:692-702. https://doi. org/10.1111/j.1600-0587.2009.05823.x

Brucet S, Boix D, Quintana XD et al (2010) Factors influencing zooplankton size structure at contrasting temperatures in coastal shallow lakes: Implications for effects of climate change. Limnol Oceanogr 55:1697-1711. https://doi.org/10.4319/lo.2010. 55.4.1697

Brucet S, Boix D, Nathansen LW et al (2012) Effects of temperature, salinity and fish in structuring the macroinvertebrate community in shallow lakes: Implications for effects of climate change. PLoS One 7(2):e30877. https://doi.org/10.1371/journal.pone. 0030877

Brucet S, Tavşanoğlu ÜN, Özen A et al (2017) Size-based interactions across trophic levels in food webs of shallow Mediterranean lakes. Freshw Biol 62:1819-1830. https://doi.org/10.1111/fwb. 12997 
Cabrera S, Compte J, Gascón S et al (2019) How do zooplankton respond to coastal wetland restoration? The case of newly created salt marsh lagoons in La Pletera (NE Catalonia). Limnetica 38(2):721-741. https://doi.org/10.23818/limn.38.42

Carmouze J, Knoppers B, Vasconcelos P (1991) Metabolism of a subtropical Brazilian lagoon. Biogeochemistry 14:129-148. https:// doi.org/10.1007/BF00002902

Carpenter SR (2003) Regime shifts in lake ecosystems: pattern and variation. International Ecology Institute, Oldendorf/Luhe

Carpenter SR, Kitchell JF, Hodgson JR (1985) Cascading trophic interactions and lake productivity. Bioscience 35:634-639

Casamitjana X, Menció A, Quintana XD et al (2019) Modeling the salinity fluctuations in salt marsh lagoons. J Hydrol 575:11781187. https://doi.org/10.1016/j.jhydrol.2019.06.018

Clavero M, Blanco-Garrido F, Prenda J (2006) Monitoring small fish populations in streams: a comparison of four passive methods. Fish Res 78:243-251

Cognetti G, Maltagliati F (2000) Biodiversity and adaptive mechanisms in brackish water fauna. Mar Pollut Bull 40:7-14. https://doi.org/10.1016/S0025-326X(99)00173-3

Comín FA, Alonso M, Lopez P, Comelles M (1983) Limnology of Gallocanta Lake, Aragon, northeastern Spain. Hydrobiologia 105:207-221. https://doi.org/10.1007/BF00025189

Comín FA, Menéndez M, Forés E (1987) Salinidad y nutrientes en las lagunas costeras del Delta del Ebro. Limnetica 3:1-8

Compte J, Gascón S, Quintana XD, Boix D (2011) Fish effects on benthos and plankton in a Mediterranean salt marsh. J Exp Mar Bio Ecol 409:259-266. https://doi.org/10.1016/j.jembe. 2011.09.005

Compte J, Gascón S, Quintana XD, Boix D (2012) The effects of small fish presence on a species-poor community dominated by omnivores: example of a size-based trophic cascade. J Exp Mar Bio Ecol 418-419:1-11. https://doi.org/10.1016/j.jembe.2012.03.004

Daan R, Gonzalez SR, Klein Breteler WCM (1988) Cannibalism in omnivorous calanoid copepods. Mar Ecol Prog Se 47:45-54

Dakos V, Scheffer M, van Nes EH et al (2008) Slowing down as an early warning signal for abrupt climate change. Proc Natl Acad Sci USA 105:14308-14312. https://doi.org/10.1073/pnas.08024 30105

Dakos V, Carpenter SR, Brock WA et al (2012) Methods for detecting early warnings of critical transitions in time series illustrated using simulated ecological data. PLoS One 7(7):e41010. https:// doi.org/10.1371/journal.pone.0041010

Demars BOL, Thompson J, Manson JR (2015) Stream metabolism and the open diel oxygen method: principles, practice, and perspectives. Limnol Oceanogr Methods 13:356-374. https://doi.org/ 10.1002/lom 3.10030

Emir Akbulut N, Tavşanoğlu ÜN (2018) Impacts of environmental factors on zooplankton taxonomic diversity in coastal lagoons in Turkey. Turkish J Zool 42:68-78. https://doi.org/10.3906/ zoo-1704-37

Esparcia A, Miracle MR, Serra M (1989) Brachionus plicatilis tolerance to low oxygen concentrations. Hydrobiologia 186(187):331-337

Frank-Gopolos T, Friis Møller E, Gissel Nielsen T (2017) The role of egg cannibalism for the Calanus succession in the Disko Bay, Western Greenland. Limnol Oceanogr 62:865-883. https://doi. org/10.1002/lno.10472

Gamito S, Gilabert J, Marcos C, Pérez-Ruzafa A (2005) Effects of changing environmental conditions on lagoon ecology. In: Gönenç IE, Wolfin JP (eds) Coastal lagoons. CRC Press, Boca Raton, Ecosystem processes and modeling for sustainable development, pp 193-229

Gascón S, Boix D, Sala J, Quintana XD (2005) Variability of benthic assemblages in relation to the hydrological pattern in Mediterranean salt marshes (Empordà wetlands, NE Iberian Peninsula).
Arch Fur Hydrobiol 163(2):163-181. https://doi.org/10.1127/ 0003-9136/2005/0163-0163

Gascón S, Arranz I, Cañedo-Argüelles M et al (2016) Environmental filtering determines metacommunity structure in wetland microcrustaceans. Oecologia 181:193-205. https://doi.org/10.1007/ s00442-015-3540-y

Gaviria S, Forró L (2000) Morphological characterization of new populations of the copepod Eurytemora velox (Lilljeborg, 1853) (Calanoida, Temoridae) found in Austria and Hungary. Hydrobiologia 438:205-216. https://doi.org/10.1023/A:1004173704289

Girgin S, Kazanci N, Dügel M (2004) On the limnology of deep and saline Lake Burdur in Turkey. Acta Hydrochim Hydrobiol 32:189-200. https://doi.org/10.1002/aheh.200400529

Glibert PM (2016) Margalef revisited: a new phytoplankton mandala incorporating twelve dimensions, including nutritional physiology. Harmful Algae 55:25-30. https://doi.org/10.1016/j.hal. 2016.01.008

Glibert PM, Boyer JN, Heil CA et al (2010) Blooms in lagoons: different from those of river-dominated estuaries. In: Kennish MJ, Paerl HW (eds) Coastal lagoons. CRC Press, Boca Raton, Critical habitats of environmental change, pp 91-113

Gliwicz ZM, Wursbaugh WA, Szymanska E (2010) Absence of predation eliminates coexistence: experience from the fish-zooplankton interface. Hydrobiologia 653:103-117. https://doi.org/10. 1007/s10750-010-0347-z

Grace MR, Giling DP, Hladyz S et al (2015) Fast processing of diel oxygen curves: estimating stream metabolism with base (BAyesian Single-station Estimation). Limnol Oceanogr Methods 13:103-114. https://doi.org/10.1002/lom.10011

Hebert PDN, Hann BJ (1986) Patterns in the Composition of Arctic Tundra Pond Microcrustacean Communities. Can J Fish Aquat Sci 43(7):1416-1425. https://doi.org/10.1139/f86-175

Heerkloß R, Hlawa S (1995) Feeding biology of two brachionid rotifers: Brachionus quadridentatus and Brachionus plicatilis. Hydrobiologia 313(314):219-221. https://doi.org/10.1007/97894-009-1583-1_30

Honti M, Istvánovics V, Staehr PA et al (2016) Robust estimation of lake metabolism by coupling high frequency dissolved oxygen and chlorophyll fluorescence data in a Bayesian framework. Inl Waters 6:608-621. https://doi.org/10.5268/IW-6.4.877

Horváth Z, Vad CF, Tóth A et al (2014) Opposing patterns of zooplankton diversity and functioning along a natural stress gradient: when the going gets tough, the tough get going. Oikos 123:461-471. https://doi.org/10.1111/j.1600-0706.2013.00575.x

Howarth R, Hayn M, Marino R et al (2014) Metabolism of a nitrogenenriched coastal marine lagoon during the summertime. Biogeochemistry 118:1-20. https://doi.org/10.1007/s10533-013-9901-x

Jagadeesan L, Jyothibabu R, Arunpandi N et al (2017) Feeding preference and daily ration of 12 dominant copepods on mono and mixed diets of phytoplankton, rotifers, and detritus in a tropical coastal water. Environ Monit Assess 189:503. https://doi.org/10. 1007/s10661-017-6215-9

James CM, Rezeq TA (1989) Intensive rotifer cultures using chemostats. Hydrobiologia 186(187):423-430

Jeppesen E, Meerhoff M, Holmgren K et al (2010) Impacts of climate warming on lake fish community structure and potential effects on ecosystem function. Hydrobiologia 646:73-90. https://doi. org/10.1007/s10750-010-0171-5

Kenitz KM, Visser AW, Mariani P, Andersen KH (2017) Seasonal succession in zooplankton feeding traits reveals trophic trait coupling. Limnol Oceanogr 62:1184-1197. https://doi.org/10. 1002/lno.10494

Kerfoot WC, DeMott WR (1984) Food web dynamics: dependent chains and vaulting. In: Meyers DG, Strickler JR (eds) Trophic interactions within aquatic ecosystems. AAAS Selected Symposium Series 85. Routledge, New York, pp 347-382 
Kunzmann AJ, Ehret H, Yohannes E et al (2019) Calanoid copepod grazing affects plankton size structure and composition in a deep, large lake. J Plankton Res 41:955-966. https://doi.org/10.1093/ plankt/fbz067

Lau DCP, Christoffersen KS, Erkinaro J et al (2020) Multitrophic biodiversity patterns and environmental descriptors of sub-Arctic lakes in northern Europe. Freshw Biol. https://doi.org/10.1111/ fwb. 13477

López-Flores R, Boix D, Badosa A et al (2006) Pigment composition and size distribution of phytoplankton in a confined Mediterranean salt marsh ecosystem. Mar Biol 149:1313-1324. https:// doi.org/10.1007/s00227-006-0273-9

Malley DF, Lawrence SG, MacIver MA, Findlay WJ (1989) Range of variation in estimates of dry weight for planktonic Crustacea and Rotifera from temperate North American lakes. Can Tech Rep Fish Aquat Sci No. 1666: iv + 49 pp

Margalef R (1978) Life-forms of phytoplankton as survival alternatives in an unstable environment. Oceanol Acta 1:493-509

McQueen DJ, Post JR, Mills EL (1986) Trophic relationships in freshwater pelagic ecosystems. Can J Fish Aquat Sci 43:1571-1581

Meerhoff M, Teixeira-de Mello F, Kruk C et al (2012) Environmental warming in Shallow Lakes: a review of potential changes in community structure as evidenced from space-for-time substitution approaches. Adv Ecol Res 46:259-349. https://doi.org/10.1016/ B978-0-12-396992-7.00004-6

Menció A, Casamitjana X, Mas-Pla J et al (2017) Groundwater dependence of coastal lagoons: the case of La Pletera salt marshes (NE Catalonia). J Hydrol 552:793-806. https://doi.org/10.1016/j. jhydrol.2017.07.034

Miracle MR, Serra M, Vicente E, Blanco C (1987) Distribution of Brachionus species in Spanish Mediterranean wetlands. Hydrobiologia 147:75-81

Monakov AV (1972) Review of studies on feeding of aquatic invertebrates conducted at the Institute of Biology of Inland Waters, Academy of Science, USSR. J Fish Res Board Canada 29:363383. https://doi.org/10.1139/f72-064

Mzozo ZB, Matcher GF, Vine NG (2019) Aspects of the feeding biology of the copepod Pseudodiaptomus hessei (Copepoda: Calanoida) under culture conditions. Aquac Res 50:1329-1337. https://doi.org/10.1111/are.14009

Nagaraj M (1988) combined effects of temperature and salinity on the compete development of Eurytemora velox (Crustacea: Calanoidea). Mar Biol 99:353-358. https://doi.org/10.1007/BF021 12127

Navarro N (1999) Feeding behaviour of the rotífers Brachionus plicatilis and Brachionus rotundiformis with two types of food: live and freeze-dried microalgae. J Exp Mar Biol Ecol 237:75-87. https://doi.org/10.1016/S0022-0981(98)00220-2

Nielsen A, Liboriussen L, Trolle D et al (2013) Daily net ecosystem production in lakes predicted from midday dissolved oxygen saturation: analysis of a five-year high frequency dataset from 24 mesocosms with contrasting trophic states and temperatures. Limnol Oceanogr Methods 11:202-212. https://doi.org/10.4319/ lom.2013.11.202

Obrador B, Pretus JL (2010) Spatiotemporal dynamics of submerged macrophytes in a Mediterranean coastal lagoon. Estuar Coast Shelf Sci 87:145-155. https://doi.org/10.1016/j.ecss.2010.01.004

Obrador B, Pretus JL (2012) Budgets of organic and inorganic carbon in a Mediterranean coastal lagoon dominated by submerged vegetation. Hydrobiologia 699:35-54. https://doi.org/10.1007/ s10750-012-1152-7

Obrador B, Staehr PA, Christensen JPC (2014) Vertical patterns of metabolism in three contrasting stratified lakes. Limnol Oceanogr 59:1228-1240. https://doi.org/10.4319/lo.2014.59.4.1228
Pagano M, Gaudy R (1986) Biologie d'un copépode des mares temporaires du littoral méditerranéen français: Eurytemora velox. I Nutrition. Mar Biol 90:551-564

Peters RH, Downing JA (1984) Empirical analysis of zooplankton filtering feeding rates. Limnol Oceanogr 29(4):763-784

Polis GA, Myers CA, Holt RD (1989) The ecology and evolution of intraguild predation: potential competitors that eat each other. Annu Rev Ecol Syst 20:297-330. https://doi.org/10.1146/annur ev.es.20.110189.001501

Putt M, Stoecker DK (1989) An experimentally determined carbon : volume ratio for marine "oligotrichous" ciliates from estuarine and coastal waters. Limnol Oceanogr 34(6):1097-1103. https:// doi.org/10.4319/1o.1989.34.6.1097

Quintana XD, Moreno-Amich R, Comín FA (1998a) Nutrient and plankton dynamics in a Mediterranean salt marsh dominated by incidents of flooding. Part 1: differential confinement of nutrients. J Plankton Res 20:2089-2107. https://doi.org/10.1093/ plankt/20.11.2089

Quintana XD, Comín FA, Moreno-Amich R (1998b) Nutrient and plankton dynamics in a Mediterranean salt marsh dominated by incidents of flooding. Part 2: response of the zooplankton community to disturbances. J Plankton Res 20:2109-2127. https:// doi.org/10.1093/plankt/20.11.2109

Quintana XD, Boix D, Badosa A et al (2006) Community structure in mediterranean shallow lentic ecosystems: Size-based vs. taxon-based approaches. Limnetica 25(1-2):303-320

Quintana XD, Arim M, Badosa A et al (2015) Predation and competition effects on the size diversity of aquatic communities. Aquat Sci 77:45-57. https://doi.org/10.1007/s00027-014-0368-1

Quintana XD, Boix D, Casamitjana X et al (2018) Management and restoration actions of confined Mediterranean coastal lagoons in the Empordà and Baix Ter wetlands. In: Quintana XD, Boix D, Gascón S, Sala J (eds) Management and restoration of Mediterranean coastal lagoons in Europe, vol 10. Recerca i Territori, pp 173-192

R-Core Team (2019) R: a language and environment for statistical computing. R Foundation for Statistical Computing, Vienna, Austria. Retrieved from https://www.rproject.org/

Ruttner-Kolisko A (1977) Suggestions for biomass calculations of plankton rotifers. Arch Fur Hydrobiol 8:71-76

Scheffer M (1998) Ecology of shalow lakes. Chapman \& Hall, London

Scheffer M (2010) Complex systems. foreseeing tipping points. Nature 467:411-412

Scheffer M, Carpenter SR (2003) Catastrophic regime shifts in ecosystems: linking theory to observation. Trends Ecol Evol 18:648656. https://doi.org/10.1016/j.tree.2003.09.002

Scheffer M, Van Nes EH (2007) Shallow lakes theory revisited: various alternative regimes driven by climate, nutrients, depth and lake size. Hydrobiologia 584:455-466. https://doi.org/10.1007/ s10750-007-0616-7

Scheffer M, Hosper SH, Meijer ML et al (1993) Alternative equilibria in shallow lakes. Trends Ecol Evol 8:275-279. https://doi.org/ 10.1016/0169-5347(93)90254-m

Scheffer M, Bascompte J, Brock WA et al (2009) Early-warning signals for critical transitions. Nature 461:53-59. https://doi.org/ 10.1038/nature08227

Scheffer M, Carpenter SR, Lenton TM et al (2012) Anticipating critical transitions. Science 338:344-348. https://doi.org/10.1126/scien ce. 1225244

Schröder A, Persson L, De Roos AM (2005) Direct experimental evidence for alternative stable states: a review. Oikos 110:3-19. https://doi.org/10.1111/j.0030-1299.2005.13962.x

Smith OL, Shugart HH, O'Neill RV et al (1975) Resource competition and an analytical model of zooplankton feeding on phytoplankton. Am Nat 109:571-591 
Staehr PA, Bade D, Van de Bogert MC et al (2010) Lake metabolism and the diel oxygen technique: state of the science. Limnol Oceanogr 8:628-644. https://doi.org/10.4319/lom.2010.8.628

Suding KN, Hobbs RJ (2009) Threshold models in restoration and conservation: a developing framework. Trends Ecol Evol 24:271279. https://doi.org/10.1016/j.tree.2008.11.012

Suding KN, Gross KL, Houseman GR (2004) Alternative states and positive feedbacks in restoration ecology. Trends Ecol Evol 19:46-53. https://doi.org/10.1016/j.tree.2003.10.005

Tavşanoğlu ÜN, Šorf M, Stefanidis K et al (2017) Effects of nutrient and water level changes on the composition and size structure of zooplankton communities in shallow lakes under different climatic conditions: a pan-European mesocosm experiment. Aquat Ecol 51:257-273. https://doi.org/10.1007/s10452-017-9615-6

Tilman D (1987) The Importance of the mechanisms of interspecific competition. Am Nat 129(5):769-774. https://doi.org/10.1086/ 284672

Tóth A, Horváth Z, Vad CF et al (2014) Zooplankton of the european soda pans: fauna and conservation of a unique habitat type. Int Rev Hydrobiol 99:255-276. https://doi.org/10.1002/iroh.20130 1646

Verdiell-Cubedo D, Oliva-Paterna FJ, Torralva M (2006) Lengthweight relationships for 22 fish species of the Mar Menor coastal lagoon (western Mediterranean Sea). J Appl Ichthyol 22:293294. https://doi.org/10.1111/j.1439-0426.2006.00738.x

Vollenweider RA, Kerekes JJ (1982) Eutrophication of waters: monitoring, assessment and control. OECD, París

Vollenweider RA, Giovanardi F, Montanari G, Rinaldi A (1998) Characterization of the trophic conditions of marine coastal waters with special reference to the NW Adriatic Sea: proposal for a trophic scale, turbidity and generalized water quality index. Environmetrics 9:329-357. https://doi.org/10.1002/(SICI)1099095X(199805/06)9:3\%3c329::AID-ENV308\%3e3.0.CO;2-9

Wallace RL, Snell TW, Ricci C, Nogrady T (2006) Guides to the identification of the microinvertebrates of the continental waters of the world 23. In: Segers, H (ed) Rotifera: Volume 1 Biology, ecology and systematics (2nd ed). Kenobi Productions, Ghent, and Backhuys Publishers, Leiden
Waterkeyn A, Grillas P, Vanschoenwinkel B, Brendonck L (2008) Invertebrate community patterns in Mediterranean temporary wetlands along hydroperiod and salinity gradients. Freshw Biol 53:1808-1822. https://doi.org/10.1111/j.1365-2427.2008. 02005.X

Wellborn GA, Skelly DK, Werner EE (1996) Mechanisms creating community structure across a freshwater habitat gradient. Annu Rev Ecol Syst 27:337-363. https://doi.org/10.1146/annurev.ecols ys.27.1.337

Werner EE, Gilliam JF (1984) The ontogenetic niche and species interactions in size-structured populations. Annu Rev Ecol Syst 15:393-425. https://doi.org/10.1146/annurev.es.15.110184. 002141

Wiggins GB, Mackay RJ, Smith IM (1980) Evolutionary and ecological strategies of animals in annual temporary ponds. Arch Fur Hydrobiol Suppl 58:97-206

Williamson CE (1983) Invertebrate predation on planktonic rotifers. Hydrobiologia 104:385-396. https://doi.org/10.1007/BF000 45996

Ye L, Chang CY, García-Comas C et al (2013) Increasing zooplankton size diversity enhances the strength of top-down control on phytoplankton through diet niche partitioning. J Anim Ecol 82:1052-1061. https://doi.org/10.1111/1365-2656.12067

Zapata M, Rodriguez F, Garrido JL (2000) Separation of chlorophylls and carotenoids from marine phytoplankton: a new HPLC method using a reversed phase C-8 column and pyridine-containing mobile phases. Mar Ecol Prog Ser 195:29-45. https:// doi.org/10.3354/meps195029

Zhang H, Urrutia-Cordero P, He L et al (2018) Life-history traits buffer against heat wave effects on predator-prey dynamics in zooplankton. Glob Chang Biol 24:4747-4757. https://doi.org/ $10.1111 /$ gcb. 14371

Publisher's Note Springer Nature remains neutral with regard to jurisdictional claims in published maps and institutional affiliations. 